\title{
Political Instability and Growth in Dictatorships
}

By: Jody Overland, Kenneth L. Simons, and Michael Spagat

Working Paper Number 354

November 2000 


\title{
Political Instability and Growth in Dictatorships*
}

\author{
Jody Overland \\ Kenneth L. Simons \\ Unaffiliated \\ Royal Holloway College \\ University of London \\ K.Simons@rhbnc.ac.uk \\ Michael Spagat \\ Royal Holloway College \\ University of London \\ M.Spagat@rhbnc.ac.uk
}

November 20, 2000

\begin{abstract}
We model growth in dictatorships facing each period an endogenous probability of political catastrophe that would extinguish the regime s wealth extraction ability. Domestic capital exhibits a bifurcation point determining economic growth or shrinkage. With low initial domestic capital the dictator plunders the country s resources and the economy shrinks. With high initial domestic capital the economy eventually grows faster than is socially optimal.
\end{abstract}

${ }^{*}$ This research was generously supported by IREX, the National Council on Soviet and East European Research and the New Economic School in Moscow. We especially thank Vadim Arkin and Alexander Slastnikov. We also thank Steven Beckman, Oded Galor, Herschel Grossman, Barry Ickes, Steven Medema, David Weil and seminar participants at Brown University, Royal Holloway College, University of Colorado, Denver, Chinese University of Hong Kong, Hong Kong University of Science and Technology, the Institute of Economics of the Academia Sinica, the 1997 Society for Economic Dynamics Conference, the 1997 GET Conference in Moscow and the 1998 CEPR-Davidson Institute Transition Economics Workshop in Prague. In addition we thank Kuo mei Chen and Okun Kovuncu for excellent research assistance. 


\section{Non-technical Summary}

It is well known that some dictatorships achieve rapid economic growth while others suffer rapid decline. Indeed, the growth rates of dictatorships vary unusually much compared to democracies. This paper is apparently the first attempt to explain this unusual variability in a formal economic framework. We can explain both rapid growth and decline in terms of optimal survival strategies for dictators in different circumstances.

The economy evolves over time with a dictator determining public capital investment in every period. Political stability, i.e., the probability that the dictator survives from period $t$ to period $t+1$ is increasing in the capital stock. The idea is that the dictator allocates the benefits of new projects so as to consolidate his power; more capital to spread around means more political stability. The dictator takes for himself and his elite group a fixed fraction of all consumption in the economy. His objective is to maximize the discounted present value of his group's consumption while he remains in office. We contrast the dictator's behavior to that of a social planner where the former does not care about economic performance after he loses power while the latter does.

Our first result is that there are only two possible qualitative paths for the capital stock: steady growth or steady deterioration. Intuitively, capital deterioration decreases stability, worsening conditions for capital investment, leading to further deterioration. On the other hand, an opposite virtuous circle underlies steady growth with mirror-image intuition. The second result is that there is steady growth when the economy begins with enough domestic capital and steady deterioration otherwise, i.e., there is a "development trap" according to which an initial domestic capital below a threshold "bifurcation point" is insufficient to allow take off. Third, we compare the dictator's behavior with a social planner's, finding that when dictatorships grow they grow faster than is optimal, i.e., faster than a social planner would choose. We believe these results illuminate rapidgrowth-at-all-costs experience of many countries including Asian Tigers. The intuition is that dictators with good survival chances impose rapid growth to further prolong their power. On the other hand, less stable dictatorships often shrink when social planners would choose to grow.

Many people argue that dictatorship offers the best hope for rapid growth in poor countries, often citing the experience of Asian Tigers in support. Others see no economic benefit in dictatorship (see the survey in Przeworski and Limongi (1993)). Our research indicates that we should indeed expect some dictatorships to grow rapidly, but we should also expect many to decline rapidly. We predict no systematic tendency toward rapid growth in dictatorships. In other words, democracies might not grow faster than dictatorships on average but they are generally a safer bet. Second, even in cases when dictatorships do grow rapidly our model suggests that this performance is not optimal from a social point of view. In other words, citizens of Asian Tigers may have sacrificed too much in support of government policy so these countries are not good examples to follow.

Next, we analyze how the bifurcation point between deterioration and growth depends on underlying parameters. It is decreasing in the dictator's discount factor and the initial level of political stability. These results make sense; a more patient or stable dictator should be more willing to pursue growth than a less patient or stable dictator. The bifurcation point is also decreasing in the depreciation rate, i.e., faster depreciation 
presents an increased threat to political stability that our dictators address directly through an enhanced tendency to grow. Increasing the penalty to the dictator for losing power also decreases the bifurcation point; since growth stabilizes the dictator's position, a strong fear of losing power is a positive factor for growth. Another way to view the same result is that dictators who are skimming a large fraction of their economy's consumption are more willing to grow than those who are skimming less because the former have more to lose from leaving office than the latter. This fits well with the theory of dictatorships developed in McGuire and Olson (1996) and particularly Olson (2000), according to which a dictator with a more "encompassing" interest, i.e., one who is taking a larger fraction, will be more willing to promote growth than one with a less encompassing interest.

We present some empirical evidence in favor of our model. Using the Barro-Lee data set (Barro (1996)) we show that countries rated to have low political rights (Gastil (1990)) vary much more in their growth rates than high political rights countries. Moreover, the former are much more likely to experience either rapid growth or decline than the latter. These results are broadly consistent with our results comparing dictatorial with social planner outcomes. Third we show, consistent with our bifurcation result, that the low political rights countries that decline tend to start with lower per capita GDP than those that experience rapid growth.

This work fits broadly into the vast economic growth literature surveyed in Barro and Sala-i-Martin (1994). To our knowledge our paper is the first rational choice model of the effect of dictatorship on growth. Barro (1996) argues that a moderate degree of dictatorship may be good for growth in poor countries. Olson (1993) argues that unstable autocrats will plunder their countries. Our results are in agreement for very unstable autocrats but not for slightly unstable ones. We predict that the latter would push for rapid growth.

We conclude that choices made by dictatorships facing instability will often vary from choices predicted by standard growth models involving benevolent social planners. Good policy analysis should acknowledge the realities of dictatorships. Failure to do so may contribute to the mixed success of foreign aid programs (Delong, 1997, Hirschman, 1981). As one step toward explicit thinking about dictatorships, our paper provides a novel perspective on how dictatorships may respond to aid. In our framework decreasing corruption actually yields lower growth, while decreasing a dictator's anticipated out-ofpower utility is good for growth. These results are due to the fact that the larger is the difference between a dictator's in-power and out-of-power utility, the greater is his determination to retain power and hence to encourage economic growth. This logic suggests that the international community focus more effort on reducing the comfort of dictators who have lost power, for example by freezing bank accounts and by prosecuting human rights violations, rather than on reducing the corruption of those who hold power. General Pinochet's recent experience in London may be good for growth in the developing world.

Keywords: Dictatorship, Growth, Political Economy, Bifurcation

JEL Classification: D9, O1, and $\mathrm{H}$ 


\section{Introduction}

Sah (1991) likens the choice of dictatorship to that of a risky asset because some grow very rapidly while others fail miserably. Robert Barro, in Getting It Right, (1996b, p.3), expresses the similar view that dictators

come in two types: one whose personal objectives often con ict with growth promotion and another whose interests dictate a preoccupation with economic development.... The theory that determines which kind of dictatorship will prevail is missing.

We actually provide such a theory. The dictators in our model come in exactly the two types Barro proposes. One forces a growth rate that is too high relative to the social optimum. The other type presides over stagnation or even plunders the economy into the ground. The determination of dictatorial type is endogenous. That is, we provide an intuitively appealing theory that determines whether a dictatorship grows or declines and that compares its performance with optimal behavior, nding a particularly high variability in growth rates in dictatorships.

Political instability is a major impediment to economic growth in a wide variety of countries. ${ }^{1}$ Instability, implying risk, limits investments and hence growth. This is recognized in the academic political economy literature in which models often include some form of political instability (i.e., Alesina and Tabellini, 1990; Grossman and Noh, 1990, 1994; Bertocchi and Spagat, 1997). Moreover, since physical capital is becoming increasingly mobile across countries and regions, the role of political instability in economic decision making is increasing as foreign investment and capital ight respond ever more sensitively to changes in countries political environments. ${ }^{2}$

While the above considerations are standard, in this paper we introduce the more novel assumption that domestic capital development contributes to political stabilization while domestic capital deterioration causes political destabilization.

\footnotetext{
${ }^{1}$ According to de la Balze (1995), Among the group of fteen most advanced prewar nations, Argentina distinguished itself ... with the greatest political instability of the postwar period (p. 4). Of course Argentina is famous for its economic decline during this long period of political instability. Other examples abound; Somalia, Haiti and the countries that comprised the former Yugoslavia are recent examples of the economic catastrophe that attends extreme political instability.

${ }^{2}$ Sachs and Warner (1995) demonstrate that global capital mobility has been growing rapidly in recent years, on its way to a return to the level it had attained in 1900.
} 
The idea underlying this relationship is that domestic capital development increases the number and in uence of individuals with an interest in the continuance of the current political status quo, stabilizing the system. ${ }^{3}$

The dictator in our model maximizes the discounted present value of his own consumption while he remains in office. His stochastic and endogenous survival process is determined by political stability, which evolves over time. ${ }^{4}$ We contrast the dictator s behavior with that of a social planner. There are two differences between the two decision makers. First, the dictator suffers a penalty if he loses power while the latter is indifferent to political upheavals. Second, the dictator s behavior is driven by the fraction of output he skims off, while in the socially planned economy nothing is skimmed off and the planner is concerned with overall consumption. ${ }^{5}$

Our rst result is that in dictatorships there are only three possible qualitative paths for domestic capital: steady growth, steady decline, or zero growth, a knifeedge case. ${ }^{6}$ In particular, a U-shape scenario under which domestic capital rst deteriorates and then reverses course cannot occur. There is a straightforward intuition underlying this result. Domestic capital deterioration decreases stability, worsening the conditions for domestic capital investment, leading to further deterioration, completing a vicious cycle. Under these conditions the dictator aggressively plunders the country s resources, even while realizing that in doing so he hastens his departure from power and, hence, his ability to continue extracting wealth. The key insight here is that in an unstable environment the dictator expects to remain in power for only a short period, regardless of his strategy, so plundering dominates investment.

\footnotetext{
${ }^{3}$ Bertocchi and Spagat (2000) provide microfoundations for this assumption. We discuss this in more detail in sections 2.5 and 2.8 .

${ }^{4}$ Our notion of dictatorship corresponds closely to the concept of tinpot dictatorship developed in Wintrobe $(1990,1998)$. Wintrobe s tinpot dictator takes as much wealth as possible subject to staying in power. We do not claim this is the only interesting kind of dictatorship. Wintrobe also emphasizes what he calls totalitarian dictatorships which strive to maximize their power. We do believe that there are not many dictatorships that do not display a signi cant tinpot element.

${ }^{5}$ We will refer often to the dictator as taking a fraction of the economy s consumption, but we do not think of the dictator taking only for himself. Rather, we think of the dictator as representing some elite group with the whole of the elite group bene ting from the taking.

${ }^{6}$ All of the results described below are based on computational analysis. Later we describe our procedures and the range of parameters checked. All the claims in this section are very robust.
} 
On the other hand, there is a self-reinforcing cycle underlying steady growth that has mirror-image intuition: domestic capital growth increases stability, improving the conditions for increased domestic capital investment leading to further growth, completing a virtuous circle. In this case, the dictator is restrained in his wealth extraction to lengthen the time he will enjoy the bene ts of continued power. In particular, more investment leads to more stability, extending the dictator s effective time horizon.

A central and related result is that if the economy begins with sufficient domestic capital to promote political stability there is steady growth; otherwise, there is steady deterioration. In other words, there is a critical level of domestic capital which we will refer to as a bifurcation point : an economy below this level nds itself in a development trap whereas one above the threshold follows a plan of steady growth. ${ }^{7}$

Next, we analyze how the bifurcation point depends on the underlying parameters. It is decreasing in the dictator s discount factor and the initial level of political stability. These results make sense; a more patient or stable dictator should be more willing to pursue growth than a less patient or stable one. ${ }^{8}$ The bifurcation point is also decreasing in the depreciation rate, i.e., faster depreciation presents an increased threat to political stability that our dictators address directly through an enhanced tendency to grow. Increasing the penalty to the dictator for losing power also decreases the bifurcation point; since growth stabilizes the dictator s position a strong fear of losing power is a positive factor for growth. Another way to view the same result is that dictators who are skimming a large fraction of their economy s consumption are more willing to grow than those who are skimming less because the former have more to lose from leaving office than the latter. This ts well with the theory of dictatorships developed in McGuire and Olson (1996) and particularly Olson (2000), according to which a dictator with a more encompassing interest, i.e., one who is taking a larger fraction, will be more willing to promote growth than one with a less encompassing interest.

The shape of the policy function, giving the fraction of output consumed as a function of domestic capital, is of interest. The consumption fraction follows two possible paths. On the rst it starts high, eventually falls and then once again increases. On the other path it falls even at low values of capital and then

\footnotetext{
${ }^{7}$ See Azariadis and Drazen (1990) and Murphy, Shleifer and Vishny (1989) on development traps.

${ }^{8}$ Although Robinson (1998) reaches the opposite conclusion on patience. We will comment more on this later.
} 
rises. This indicates that at an early stage of development dictatorships increase their saving rates as they grow richer. This result provides insight into the rapid growth experience of the Asian Tiger economies that did indeed have declining consumption rates during their takeoff phases (Mankiw, Romer, and Weil, 1992).

We then explore the differences between the dictator $\mathrm{s}$ and social planner $\mathrm{s}$ behavior. The most glaring distinction is that the social planner does not exhibit bifurcation. In fact, for the parameters we consider the social planner always grows. ${ }^{9}$ Next, for sufficiently high domestic capital dictatorships grow (sub-optimally) faster than their corresponding social planner economies. The intuition is that a dictator expects high growth rates to prolong his tenure in power. Thus, when a dictator chooses growth, he will eventually choose rapid growth in order to increase the longevity of his rule. ${ }^{10}$ This ts with empirical evidence that democracy may actually slow growth (Barro, 1996a). On the other hand, dictatorships below the bifurcation point shrink when, with the same endowment, social planners grow. This reveals a tendency for dictators to plunder their countries wealth when their hold on power is insecure. We also nd that the variability of growth rates for our dictators is higher than for our social planners.

These results have interesting connections with some common ideas on growth and dictatorship. First, one often encounters the view that corrupt regimes have a strong tendency to decline. ${ }^{11}$ But, within our framework this is not necessarily the case. Below the bifurcation point our regimes, which are by nature corrupt in the sense that they appropriate national wealth for themselves, do indeed decline rapidly. But sufficiently above bifurcation they grow very rapidly. This is not to

\footnotetext{
${ }^{9}$ Of course, there are circumstances in which it can be optimal for the economy to shrink, e.g., if time discounting is very strong, but we normally do not consider these to be interesting cases.

${ }^{10}$ De Long (1997, ch.2) shows that from the 1960s many dictatorships in the non-Communist fringe of Paci c Asia and in Saharan Africa have experienced rapid growth.

${ }^{11}$ Barro (1996a) states: ... the effects of an autocracy are adverse, however, if the dictator uses his or her power to steal the nation s wealth... Bardhan (1997) writes, when public resources meant for building productivity-enhancing infrastructure are diverted for politicians private consumption... growth rates obviously will be adversely affected. De Long (1997) lists a group of countries that did not follow the above-bifurcation growth path in which ...the average person is probably poorer in absolute terms than their counterparts back in 1965... This group includes Mozambique, Togo, Ethiopia, Tanzania, Senegal, Ghana, Zaire (now Republic of Congo), Uganda, Argentina, Bolivia, Chile, El Salvador, Peru, Nicaragua, and Jamaica. De Long attributes these countries steady decline to Government by Thieves or kleptocracy situations where the leaders have sacri ced economic development and the long-run interests of all to the short run interests of a relative few (ch. 21, p. 3).
} 
say that our results would support a view that dictatorships are socially optimal. In fact, our model dictatorships do not choose socially optimal growth rates, but they may experience especially rapid growth. A second common view is that insecure dictators will tend to plunder their economies into decline (e.g. Olson, 1991, 1993). Again, this is true only below bifurcation in our model. It is true that instability leads to what we call a horizon-shortening effect that operates against growth in all cases. But at the same time there is also an endogenoussurvival effect that works in the opposite direction. Since rapid investment shifts to the right the probability distribution over the dictator s time in power, there is a tendency for overinvestment by moderately insecure dictators. In other words, a desire to stabilize his position might lead a dictator to favor rapid growth.

Finally, we present some empirical evidence in favor of our model. Using the Barro-Lee data set (Barro, 1996a) we show that countries rated to have low political rights (Gastil, 1990) vary much more in their growth rates than high political rights countries. ${ }^{12}$ Moreover, the former are much more likely to experience either rapid growth or decline than the latter. These results are consistent with our theoretical results comparing model dictatorships with social planner outcomes. Moreover, this section moves forward the large literature surveyed in Przeworski and Limongi (1993) that has asked whether or not dictatorships grow faster than democracies on average but has yielded only inconclusive results. While democracies may or may not have faster average growth rates than dictatorships they certainly seem to be a much safer bet for steady growth. Finally, we show, consistent with our bifurcation result, that the low political rights countries that decline tend to start with lower per capita GDP than those that experience rapid growth.

Wintrobe $(1990,1998)$ provides a general theory of dictatorships of all possible types. The main concern in this pathbreaking work is how dictators maintain power through the use of repression, economic growth and distribution of rents. Although we do not consider repression here, our idea of stabilization through growth, underpinned by the enhanced opportunities for co-optation of potential opposition that growth affords, are very much along the lines of Wintrobe s thinking. ${ }^{13}$ However, Wintrobe s analysis does not delve into the dynamics of the growth process and, therefore, is unable to do, e.g., the sorts of comparisons be-

\footnotetext{
${ }^{12}$ Lucas (1988) points out that growth rates tend to be far less stable in developing countries than in established democracies, but the growth literature has not followed up on this idea. In our model the characteristics of a dictator, or more generally of the ruling group, determine growth paths so replacement of one group with another could switch a country from decline to rapid growth or vice versa.

${ }^{13}$ See Spagat (1999) for a dynamic model of repression.
} 
tween the growth rates of dictatorships and social planners that feature centrally in our work.

Marcouiller and Young (1995) provide an interesting static model of a predatory state showing how, through general equilibrium effects, the threat that economic activity will withdraw into the informal economy to avoid corrupt taxation can be very weak. They give circumstances under which it can be rational for a dictator to tax the formal sector very heavily while simultaneously providing virtually no public goods. This work is, however, concerned solely with negative outcomes and also does not study dynamics.

Robinson (1998) studies the question of whether states promote development or simply prey off the population. The key tradeoff in this work is that development expands the pie from which a state can siphon off resources but also can make it easier for opposition to organize against the state. A good example of the issue is building roads; roads are good for development but also can be used for subversive activity. Interestingly, in this theory patient dictators can be among the least development-oriented because they are the most averse to the possible future political destabilization that public investment could cause. We believe this work gives very important insights, particularly into the large number of corrupt regimes that have stagnated and deteriorated over time. However, we also think that many important cases t into our complementary approach that treats growth as stabilizing rather than destabilizing. ${ }^{14}$ In fact, many Asian regimes in particular seem to derive their legitimacy mainly from their ability to deliver economic growth.

Feng and Zak $(1998,1999)$ study the transition from dictatorship to democracy. In the present paper a political catastrophe can just as easily be a transition from one dictatorship to another as from dictatorship to democracy. Moreover, we focus more on the behavior determined by the desire to avoid catastrophe than on the actual occurrence of catastrophes. Nevertheless, there is an obvious overlap in the two approaches.

Grossman and Noh (1990, 1994) model a dynamic and endogenous survival process for what they call a proprietary regime, although they are concerned with taxation issues rather than growth. Papers starting with Perotti (1993), Alesina and Rodrik (1994), and Persson and Tabellini (1994) combine politics and growth, although they all work within a democratic framework with majority voting and study the effects of inequality. There are various other non-growth but dynamic political economy models. Dewatripont and Roland (1992) and

\footnotetext{
${ }^{14}$ See Section 2.8 for further discussion.
} 
Rodrik (1996) focus on the political economy of transition and policy reform, inherently dynamic contexts. Our focus on growth, the dangers of overthrow and the dictator $\mathrm{s}$ incentives is thus complementary to these other studies.

The plan of the paper is as follows. In section two we present the model. Results are presented and analyzed in section three. We give some evidence for our theory in section four and conclude in section ve.

\section{The Model}

\subsection{Production}

The economy s production function is

$$
F_{t}=\nu K_{t}^{\alpha} J_{t}^{1-\alpha}
$$

where $K_{t}$ is domestic and non-mobile capital and $J_{t}$ is foreign and fully-mobile capital at time $t$ respectively and where $t=1,2, \ldots$ is measured in discrete intervals. We think in terms of a broad concept of domestic capital that goes beyond traditional physical capital to include physical infrastructure (roads, bridges, telephone lines etc.), market infrastructure (stock, bond, and derivatives markets, banks, a functioning legal system etc.), and human capital. Foreign capital is complementary to domestic capital and includes such factors as advanced technology, sophisticated physical capital and modern managerial skills factors of production not readily available in the domestic economy.

\subsection{Foreign Investment}

We assume a small open economy, i.e., foreign investment ows into or out of the country until its domestic return is equal to a xed world rate of return, $\rho .^{15}$ Therefore $\rho=\frac{\partial F_{t}}{\partial J_{t}}=\nu(1-\alpha) J_{t}^{-\alpha} K_{t}^{\alpha}$. Solving for $J_{t}$ yields

$$
J_{t}=\left(\frac{\nu(1-\alpha)}{\rho}\right)^{\frac{1}{\alpha}} K_{t}
$$

\footnotetext{
${ }^{15}$ The foreign investment ensures constant returns to domestic capital. Some such device is appropriate to abstract away from returns-to-scale phenomena and focus solely on how outcomes may derive from the nature of dictatorships. Alternatively, in-country production could be assumed to have a constant returns production function with no foreign investment.
} 


\subsection{The Rate of Return on Domestic Capital}

Domestic capital earns its marginal product, so that its rate of return $w_{t}$ is

$$
w_{t}=\frac{\partial F_{t}}{\partial K_{t}}=\nu \alpha J_{t}^{1-\alpha} K_{t}^{\alpha-1}=\nu^{\frac{1}{\alpha}} \alpha\left(\frac{1-\alpha}{\rho}\right)^{\frac{1-\alpha}{\alpha}}
$$

Since it turns out that $w_{t}$ does not vary over time, we de ne $w \equiv w_{t}$ so as not to unnecessarily carry the $t$ subscript through all the calculations. Gross domestic earnings are $w K_{t}$ and are decreasing in the world rate of return. Note that the production function is homogeneous of degree one so, using Euler s theorem, $F_{t}=\nu K_{t}^{\alpha} J_{t}^{1-\alpha}=w K_{t}+\rho J_{t}$.

\subsection{Domestic Capital Development}

Let $C_{t}$ denote consumption and de ne investment as $I_{t}$ where $I_{t} \equiv w K_{t}-C_{t}$. The difference equation governing domestic capital evolution is

$$
K_{t+1}=(1-\delta) K_{t}+I_{t},
$$

where $0 \leq \delta \leq 1$ is the rate of decay of capital. This formulation builds some persistence into the domestic capital stock while requiring investment if the stock is to be maintained or increased.

\subsection{Political Catastrophes}

A key feature in the model is that in every period there is an endogenous probability of a political catastrophe that removes the dictator from power. The catastrophe probability in period $t$ is given by

$$
q_{t}=q\left(K_{t}\right)=\min \left(e^{\eta+\theta K_{t}}, 1\right)
$$

where $\theta<0 .{ }^{16}$ This is the probability that the dictator is not in power during year $t+1$ given that he was in power during year $t$. Thus, the transition out of power occurs at the end of year $t$. In the computations $\eta$ is chosen so that $\eta+\theta K_{t}<0$ for all plausible values of $K_{t}$. The idea is that as domestic capital grows the number

\footnotetext{
${ }^{16}$ Of course, probabilities must be between zero and one, hence the use of the minimum operator.
} 
and in uence of people who have a stake in preventing a catastrophe grow and, therefore, the catastrophe probability decreases. This is intuitive. As human capital, physical infrastructure and market infrastructure grow, the number of people with high earning power under the current regime also grows. These people and interests will naturally wish to prevent catastrophes. ${ }^{17}$

\subsection{Objective of the Policymaker}

We are interested in the behavior of a dictatorship concerned with the portion of domestic consumption it takes in every period up until a catastrophe point if one occurs. The dictator chooses the split of output between consumption and investment, but not the fraction of consumption he appropriates. Consumption for the dictator is $\lambda C_{t}$ where $0<\lambda<1$. The dictator s utility in period $t$ is

$$
U_{t}=\left\{\begin{array}{c}
\frac{\left(\lambda C_{t}\right)^{1-\sigma}}{1-\sigma} \text { if } \sigma \neq 1 \text { and in power } \\
\ln \left(\lambda C_{t}\right) \text { if } \sigma=1 \text { and in power } \\
U_{\min } \text { if not in power }
\end{array}\right\}
$$

where $\sigma \geq 0$ is the coefficient of relative risk aversion. The last line re ects the key fact that the dictator is penalized for losing power. $U_{\min }$ and $\lambda$ are taken as a parameters that are varied in the computations to re ect different penalties for losing power. $U_{\min }$ in the computation is chosen so that for any reasonable capital stock the utility in power is higher than utility out of power.

Assuming a discount factor of $0<\beta<1$ and subject to equations $2.1-2.6$, the dictator s problem can be written as

$$
\max _{\left\{C_{t}\right\}_{t=1}^{\infty}} E \sum_{t=1}^{\tau} \beta^{t} U_{t}+\frac{\beta^{\tau+1}}{1-\beta} U_{\text {min }}
$$

where $\tau$ is a random variable with range $\{1,2, \ldots\}$ giving the stochastic and endogenous time when the catastrophe occurs. An equivalent formulation for the problem is

\footnotetext{
${ }^{17}$ A companion paper by Bertocchi and Spagat (2000) establishes microfoundations for this assumption based on the notion that development enhances a dictator s ability to co-opt potential opposition through spreading wealth around. Alternatively, we studied a variant of the model in which consumption replaces capital in the catastrophe function. This effectively makes the population extremely myopic. Most, but not all, of our qualitative results still hold in this case. Details are available from the authors upon request.
} 


$$
\max _{\left\{C_{t}\right\}_{t=1}^{\infty}} E \sum_{t=1}^{\infty} \beta^{t}\left\{\left[\prod_{\tau=1}^{t}\left(1-q\left(K_{\tau}\right)\right)\right] U\left(C_{t}\right)+\left[1-\prod_{\tau=1}^{t}\left(1-q\left(K_{\tau}\right)\right)\right] U_{\min }\right\}
$$

where $\prod_{\tau=1}^{t}\left(1-q\left(K_{\tau}\right)\right)$ is the endogenous probability that the dictator is in power at time $t$ and $1-\prod_{\tau=1}^{t}\left(1-q\left(K_{\tau}\right)\right)$ is the endogenous probability that the dictator is not in power at time $t$.

Next, as a basis for comparison, we consider the problem of a benevolent social planner. This problem coincides with the dictator s problem, but with one key difference; the social planner does not view political catastrophe as terminating high utility. The difference between the criteria of the social planner and the dictator is that the dictator weighs a given future period s utility by the probability of avoiding catastrophe up to that point, while the social planner takes into account the path of the economy after catastrophe. After a political upheaval, the economy continues on with different leadership but still provides utility to the population. The planner s problem is thus given by

$$
\max _{\left\{C_{t}\right\}_{t=0}^{\infty}} E \sum_{t=1}^{\infty} \beta^{t} U\left(C_{t}\right)
$$

where $U\left(C_{t}\right)=\left\{\begin{array}{c}\frac{\left(C_{t}\right)^{1-\sigma}}{1-\sigma} \text { if } \sigma \neq 1 \\ \ln \left(C_{t}\right) \text { if } \sigma=1\end{array}\right\}$.

One way to understand the difference between (2.7) and (2.9) is that the sum in the former runs from 0 to the random $\tau$ (with utility $U_{\min }$ thereafter) while the latter runs with certainty to $\infty$. Equation (2.8) seems to suggest that the possibility of political catastrophe, and hence the termination of the dictator s reign, acts simply to intensify time discounting. Although there is some truth in this it misses the most crucial point about the model; the dictator s survival probability is endogenously determined. Thus, our formulation allows the dictator, in effect, control over discounting: a factor that is the key to our analysis.

\subsection{Dynamic Programming Formulation}

The Bellman equation for the dictator s problem is

$$
V^{d}(K)=\max _{0 \leq C \leq w K} U(C)+\beta\left\{[1-q(K)] V^{d}([1-\delta] K+I)+q(K) V_{\min }\right\}
$$


Equation (2.10) just says that the value $V^{d}$ to a dictator of a given level of domestic capital, having avoided catastrophe this period, is the utility of consumption plus the value of the resultant domestic capital next period discounted by $\beta$ and the probability of avoiding catastrophe plus the value of losing power times its probability also discounted by $\beta$. It is well known that this formulation is equivalent to (2.7).

Similarly, the Bellman equation for the social planner is

$$
V^{p}(K)=\max _{0 \leq C \leq w K} U(C)+\beta V^{p}([1-\delta] K+I)
$$

\subsection{Discussion of the General Set-up}

To elucidate the meaning of political catastrophe, we offer the following examples. Communist revolutions would always qualify as political catastrophes, because they curtail the ability of the overthrown elite to enjoy the bene ts of power. An electoral defeat of a ruling party may or may not qualify. The key question is whether defeat leads to a substantial cut in the party s ability to extract resources from the economy. In democracies transfers of power often do involve substantial shifts in political patronage lines. When these are large our model can give insights into the situation. A good example would be the Russian election of 1996 when if Gennadi Zyganov had defeated Boris Yeltsin this would have constituted a political catastrophe achieved through democratic means. When democratic transfers of power do not have strong nancial implications for the party in power we would not consider them political catastrophes and this paper would not have much to offer. Most elections in mature democracies would tend to have this character. Thus, political catastrophe, as we de ne it, is not synonymous with revolution although revolutions typically would be political catastrophes. Some democratic transfers of power can satisfy our de nition. The key requirement is that there must be a major decrease in ruling elites ability to extract resources.

Next consider our working hypothesis that more domestic capital causes greater stability. Might it not be more sensible to posit that public pressure punishes a dictator for deviating too far from the behavior of a social planner rather than for not building a large enough capital stock? It might be sensible for a homogenous public to establish a survival probability for a dictator that decreases in the distance of economic policy from optimality. However, consider the following micro underpinning for our hypothesis. At the beginning there are two groups, an elite group (the dictator s people) and a non-elite group (people who would like 
to overthrow the dictator). Imagine the probability of overthrow is an increasing function of the size of the non-elite group. Now suppose the elite co-opts, e.g., by transferring some wealth, some members of the non-elite into joining a third group that is politically neutralized, i.e., that does not actively oppose the dictator. It is intuitively plausible that the wealthier is the elite the larger will be the fraction of the non-elite the former is able to co-opt. That is, a larger capital stock at the disposal of the elite will allow it to buy more political stability. ${ }^{18}$

Of course, this cannot be considered an iron law of nature. In certain situations rapid growth may be destabilizing (see Olson, 1963; Robinson, 1998). However, note that the overthrow of an autocrat following an episode of rapid growth does not necessarily mean that the growth was a destabilizing factor. For example, before World War I when Russia was experiencing rapid growth Prime Minister Stolypin initiated his wager on the strong and sober, a policy that brought ambitious peasants into the middle class. Lenin greatly feared this policy, opining that if this should continue for very long periods of time ... it might force us to renounce any agrarian program at all. (Moorhead, 1958, p. 69). Within the framework of our model we can see the rapid growth as a survival strategy re ecting the insecurity of the tsar who simply was not sufficiently fortunate to hang on long enough to achieve full stability. In fact, taking seriously the stochastic nature of our survival process we should expect a certain number of cases like Russia that experience rapid growth and then political catastrophes; they just should not be the typical case. Indeed, Przeworski et. al. (1996) and Przeworski and Limongi (1997) show that growing dictatorships are much less likely to democratize than shrinking ones, i.e., on average growth tends to be stabilizing for dictatorships. ${ }^{19}$

\footnotetext{
${ }^{18}$ Bertocchi and Spagat (2000) formalizes this argument.

${ }^{19}$ Of course, this is not to say that Olson (1963) and Robinson (1998) are wrong. There may be, e.g., a useful way of taking a sub-sample of the large sample used in Przeworski et. al. (1996) and Przeworski and Limongi (1997) that would not display the characteristic that growth is a stabilizing force.
} 


\section{Results}

\subsection{The Basic Approach}

The problem is too complicated to yield an analytical solution so we solve it numerically. ${ }^{20}$ Table one gives the parameter values included in the computations. Our goal was to be as realistic as possible. For standard parameters we used typical values from the growth literature. In fact, everything is entirely standard except for the parameters of the catastrophe function, which does not have any close counterpart in any established literature we know of. For this reason we ranged over a large number of parameters for the catastrophe function. There are a total of 432 parameter sets. We give details of the computational procedure in the appendix. Table 1 gives the computational grid.

\section{[TABLE 1 ABOUT HERE]}

\subsection{Dependence on Initial Domestic Capital Bifurcation}

In 429 out of the 432 cases there is a bifurcation point for domestic capital in the solution to the dictator s problem. That is, in these cases if initial domestic capital begins above some level $\bar{K}$, then it will always increase, but if domestic capital begins below $\bar{K}$ it will always decrease. The remaining 3 cases involve growth even for very low values of $K$. As gure 1 shows, most of the bifurcation points are in the range between $\$ 1$ billion and $\$ 10$ billion. The values of $\mathrm{K}$ shown range from $\$ .1$ billion to $\$ 1$ trillion, and the horizontal axis is logarithmic, with each interval indicating a multiple of ten in $\mathrm{K}$. The plot is very slightly smoothed (otherwise it would consist of spikes) using kernel density methods, with 201 points and a kernel half-width of 0.025 , ensuring that the ne structure of the distribution remains apparent. $^{21}$

\footnotetext{
${ }^{20}$ It is well known that deterministic Cass-Koopmans growth models yield analytical solutions only for a handful of special functional forms. Not only does our model have uncertainty, but the stochastic component enters in a non-standard and deceptively difficult way with the randomness depending on the endogenous capital stock. This makes the model very difficult to handle analytically.

${ }^{21}$ Forty-two cases display bifurcation at points off the graph, all between $\$ .05$ billion and $\$ .1$ billion.
} 


\section{[FIGURE 1 ABOUT HERE]}

The main reason for this behavior is captured by the following mechanism. If initial domestic capital is low the dictator has a low probability of retaining power for very long. Thus, it is pointless to invest and, therefore, he allows the capital stock to deteriorate while he plunders the economy. This is consistent with the idea that insecure dictators do not favor growth (Olson, 1991, 1993). On the other hand, if initial domestic capital is relatively high the dictator can look forward to a long reign in power and therefore will wish to invest, further delaying his expected departure date. In this case, the dictator s strategy is to restrain his plundering in exchange for increasing his time in power. Thus, moderate insecurity is consistent with economic growth. Clague et. al. (1996) show empirically that dictators who are in power for a long time are more restrained in their plundering, in the sense that they give more respect to property and contract rights, than those who are in power for a short period of time.

The following proposition further develops the bifurcation intuition.

Proposition 3.1. Suppose the dictator s value function, $V^{d}(K)$ in equation 2.10, is strictly concave and differentiable. Then if the capital stock in period $t+1$ is (weakly) larger than the capital stock in period $t$, the capital stock in any period $\tau>t$ will always be (weakly) larger than the capital stock in period $\tau-1$. Conversely, if the capital stock in period $t+1$ is (weakly) smaller than the capital stock in period t, the capital stock in any period $\tau>t$ will always be (weakly) smaller than the capital stock in period $\tau-1$.

Proof. Suppose $K_{t+1} \geq K_{t}$ but, contrary to the proposition, $K_{t+2}<K_{t+1}$. This would imply that $C_{t+1}>C_{t}$. Note that the solution to the maximization problem on the RHS of the Bellman equation (2.10) must be an interior solution. Consider the rst order conditions for this solution at both time $t$ and time $t+1$. They are

$$
U^{\prime}\left(C_{t}\right)+\beta\left[1-q\left(K_{t}\right)\right] \frac{d V^{d}\left(K_{t+1}\right)}{d K}=0
$$

and

$$
U^{\prime}\left(C_{t+1}\right)+\beta\left[1-q\left(K_{t+1}\right)\right] \frac{d V^{d}\left(K_{t+2}\right)}{d K}=0
$$

But $U^{\prime}\left(C_{t}\right)>U^{\prime}\left(C_{t+1}\right), 1-q\left(K_{t}\right) \leq 1-q\left(K_{t+1}\right)$ and $\frac{d V^{d}\left(K_{t+1}\right)}{d K}<\frac{d V^{d}\left(K_{t+2}\right)}{d K}$ which leads to a contradiction. Therefore if the capital stock ever increases it can never again decrease. 
The proof of the claim that once capital shrinks it continues to shrink is a mirror image of the above argument.

The computations indicate that the dictator s value function is strictly concave only for 50 of the 432 parameter sets tested so the proposition is of limited applicability. On the other hand, the computed value functions are nearly always concave at sufficiently low and high values of $\mathrm{K}$ (all but about 25 are strictly concave near $\mathrm{K}=\$ .1$ billion and all are strictly concave near $\mathrm{K}=\$ 1$ trillion) so the proposition does provide insight for all of the cases. ${ }^{22}$

If we interpret $K$ as human capital then this bifurcation result has an interesting connection with the issue of human capital investment in Russia. It is often argued that human capital should be allowed to deteriorate temporarily at an early stage in Russia s transition process while other more pressing concerns are attended to. ${ }^{23}$ According to this view human capital growth could resume after stability has been achieved. But the present model suggests that such a U-shaped scenario might not be a feasible path for Russia.

\subsection{Bifurcation Sensitivity and Parameter Choice}

The computations yield the following unambiguous results on how the bifurcation point, when it exists, responds to changes in underlying parameters. The bifurcation point is decreasing in $\beta, \lambda$ and $\delta$. The rst is the unsurprising result that patient dictators are more development-oriented than impatient ones. An interpretation of the second result is that the more lucrative it is to run the country the more interested the dictator will be in growth because growth stabilizes his position and creates a larger pie to steal from. The third indicates that rapidly depreciating capital sufficiently threatens political stability to produce a strong growth inclination. The bifurcation point is increasing in $U_{\min }$, i.e., dictators expecting a soft landing after losing power are less interested in growth than those who expect to suffer more when out of power. This is because growth is stabilizing so the more determined is a dictator to hold power the more inclined he is to foster growth. ${ }^{24}$ The bifurcation point is increasing in political instability (as

\footnotetext{
${ }^{22}$ Also, the computations employ a very strict concavity test that may sometimes indicate lack of concavity as a result of computational inaccuracy, so the proposition may provide insight even for some of the functions that fail the test in the regions in which they fail.

${ }^{23}$ For details see Overland and Spagat (1996) and Fan, Overland and Spagat (1999) who argue against the common view.

${ }^{24}$ The results for $\lambda$ and those for $U_{\min }$ are just different ways of presenting the same thing. Since the solution to the problem does not change when the utility function is multiplied by a
} 
measured by $q_{1}(\$ 10$ billion), see table 1$)$ is bad for growth. The bifurcation point does not respond systematically to changes in $\sigma$ or to changes in $\theta$ and $\eta$ that hold $q_{1}$ xed.

The effect of changing $q_{1}$ may be of special interest if we consider that different countries may have different $q_{1}$ s due to exogenous factors. For example, one might argue that Taiwan and South Korea in the 1950s were able to achieve higher political stability at a similar level of development than was the Philippines, due to higher equality resulting from land reform. The differences in $q_{1} \mathrm{~s}$ might have put these countries on different sides of their respective bifurcation points, at least for some time periods, resulting in the large differences in per capita GDPs they have achieved today.

\subsection{The Dictator s Policy Function}

It is interesting to note the non-monotonicity of the consumption fraction as a function of domestic capital (hence income). In most of the cases the consumption fraction starts high, then falls, and then rises again. In the rest it decreases even at low $\mathrm{K}$ and then rises. The reason for this behavior is closely connected with the above discussion of bifurcation. If domestic capital is below the bifurcation point, then the optimal choice is to allow it to deteriorate. This implies that an increase in domestic capital that does not push the economy above the bifurcation point simply leads to higher current consumption. When the bifurcation point is crossed, however, the basic plan shifts from plundering the economy and extinguishing domestic capital to building it up. There is then an interval of higher domestic capital levels over which improved conditions for investing in domestic capital induce the policymaker to cut the consumption rate. The bifurcation point for an economy generally occurs near the beginning of this interval of declining consumption. At even higher levels of domestic capital, the consumption fraction once again begins to increase. This is consistent with the experience of Asian tigers who increased their saving rates at early stages of industrialization (Mankiw, Romer and Weil, 1992).

\subsection{The Dictator Versus the Social Planner}

The crucial difference between the planner and the dictator is that the planner does not exhibit bifurcation. In fact, for all the parameter values we used the constant what really matters is the size of $U_{\min }$ relative to the other piece of the utility function. 
social planner chooses positive growth for any initial domestic capital stock. So whenever our model dictatorships shrink it is always socially sub-optimal to do so.

Next, when the dictatorial economy has an initial domestic capital level sufciently above its bifurcation point, it achieves a higher growth rate than the comparable socially-planned economy, i.e., it grows faster than is socially optimal. The intuition behind this result is that the dictator, but not the social planner, cares about the probability of survival. This endogenous probability is increased by heavy investment in domestic capital (equation 2.5). Thus, the dictator has a unique incentive to push for a high growth rate.

It is, perhaps, surprising that there are any circumstances at all under which the dictator outgrows the social planner. The dictator, in effect, discounts the future more than the planner because the former s planning horizon is truncated (stochastically) by the possibility that he will be removed from power. How is it that the one who discounts the future most strongly invests the most? The dictator can affect his survival prospects through his investment strategy: more investment leads to a longer expected term in office. Thus, the endogeneity of the political catastrophe is the reason for high investment. ${ }^{25}$

These considerations can be clearly displayed in the following manner. First, using 2.11, a solution to the dictator s problem starting from an initial capital stock $K,\left\{C_{t}^{d}\right\}_{t=1}^{\infty}$ must have the property that $C_{1}^{d}$ solves

$$
\begin{aligned}
& \max _{0 \leq C \leq w K} U(C)+\beta[1-q(K)] \times \\
& \left\{U\left(C_{2}^{d}\right)+\beta\left\{1-q\left[K_{2}(C)\right]\right\} V^{d}\left(K_{3}(C)\right)+\beta q\left[K_{2}(C)\right] U_{\min }\right\} \\
& +\beta q(K) U_{\min }
\end{aligned}
$$

where $K_{2}(C)=(1-\delta) K+w K-C$ and $K_{3}(C)=(1-\delta)[(1-\delta) K+w K-C]+$ $w[(1-\delta) K+w K-C]-C_{2}^{d}$. This problem can be interpreted as choosing consumption in period 1 subject to the constraints that the decision-maker will consume $C_{2}^{d}$, the quantity the (optimizing) dictator would consume in period 2, and then receive the continuation utility associated with the capital stock implied by

\footnotetext{
${ }^{25}$ Roberts and Rodriguez (1997) provide an interesting growth model for Soviet-type economies. They explain why transition economies have invested much less than their centrally planned parents by invoking a change in the applicable discount rate. But in our model the planner and the dictator always have the same discount rate, strictly de ned.
} 
his choice in period 1 and $C_{2}^{d}$. A solution to the planner s problem starting from an initial capital stock $K,\left\{C_{t}^{p}\right\}_{t=1}^{\infty}$, must have the property that $C_{1}^{p}$ solves

$$
\max _{0 \leq C \leq w K} U(C)+\beta\left[U\left(C_{2}^{p}\right)+\beta V^{P}\left(K_{3}(C)\right)\right]
$$

This problem can be interpreted as choosing consumption in period 1 subject to the constraints that the decision-maker will consume $C_{2}^{p}$, i.e., the quantity the (optimizing) social planner would consume, in period 2 and then receive the continuation utility associated with the capital stock implied by his choice in period 1 and $C_{2}^{p}$. These problems yield, for the dictator and social planner respectively, the rst order conditions

$$
\begin{array}{ll}
0= & U^{\prime}(C)+\beta^{2}[1-q(K)] q^{\prime}\left[K_{2}(C)\right]\left\{V^{d}\left[K_{3}(C)\right]-U_{\min }\right\} \\
+ & \beta^{2}[1-q(K)]\left\{1-q\left[K_{2}(C)\right]\right\} \frac{\partial V^{d}\left[K_{3}(C)\right]}{\partial K_{3}} K_{3}^{\prime}(C)
\end{array}
$$

and

$$
0=U^{\prime}(C)+\beta^{2} \frac{\partial V^{P}\left[K_{3}(C)\right]}{\partial K_{3}} K_{3}^{\prime}(C)
$$

It is clear, from comparing the third term in 3.5 with the second term in 3.6, that for the dictator the marginal value of more capital next period is discounted by the extra $[1-q(K)]\left\{1-q\left[K_{2}(C)\right]\right\}$ relative to the planner. This horizonshortening effect argues for less investment. On the other hand, the dictator s term $\beta^{2}[1-q(K)] q^{\prime}\left[K_{2}(C)\right]\left\{V\left[K_{3}(C)\right]-U_{\min }\right\}>0$ in 3.5 re ects an endogenous-survival effect that argues for more investment. It turns out that the latter effect dominates the former far enough above bifurcation.

The present result can be further understood by comparing typical dictators and planners policy functions as shown in gure 2. The gure compares the two optimal functions using identical parameter values. Above bifurcation consumption in the dictatorial economy falls to a level below that in the planner s economy, leading to faster growth. For high levels of domestic capital, policies of the dictator and social planner converge because instability is extremely low (equations 2.10 and 2.11 demonstrate this mathematically). Indeed, when the threat of political overthrow is tiny, the dictator and social planner become indistinguishable.

[FIGURE 2 ABOUT HERE] 
Figure 3 gives a picture of the distribution of capital stocks at which the dictator s consumption dips below that of the social planner ranging over all the parameter values we studied. Note that the capital stocks required for the dictator to outgrow the planner are not especially high; all of these cut-through points are below $\$ 100$ billion and $74 \%$ of them are below $\$ 10$ billion. We also studied the response of cut-through points to changes in underlying parameters and got exactly the same qualitative results as we had for the response of bifurcation points to parameter changes.

\section{[FIGURE 3 ABOUT HERE]}

The magnitude of cut-through is quite signi cant. An average of 1.4 orders of magnitude ( 686.8 grid points) within the range $\mathrm{K}=\$ .1$ billion to $\$ 1$ trillion involved the dictator s consumption strictly less than the social planner s. The various parameter sets ranged from 0.69 to 2.88 orders of magnitude (343 to 1441 grid points) in which the dictator s consumption was lower over that range. Among the values of $\mathrm{K}$ for which the dictator s $\mathrm{C}$ was lower, the dictator on average chose $26.1 \%$ less consumption than the social planner (with the mean percentage below ranging from $2.8 \%$ to $52.3 \%$ for alternative parameter sets). Again, among the values of $\mathrm{K}$ for which the dictator s $\mathrm{C}$ was lower, the dictator on average had a growth rate higher by 0.0044 ( $0.44 \%$ per annum) than the social planner (with the amount higher ranging from 0.000017 to 0.0174 for alternative parameter sets). The differences in growth rates were much more pronounced than these averages at values of $\mathrm{K}$ shortly after the cut-through.

Finally, we note that our model dictatorships display much more variability in growth rates than do the model social planner economies. In particular, the standard deviation of growth rates, ranging over all parameter values and a sampling of 2001 logarithmically equally spaced initial $K s$, (ranging from $\$ .1$ billion to $\$ 1$ trillion) is 13.1 for the dictator and 7.4 for the social planner. The high variability for the dictator is due to strong policy response to varying $K$ rather than to response to changing parameter values.

\section{Some Evidence}

There is a large empirical literature on growth and political regimes surveyed in Przeworski and Limongi (1993) and Sirowy and Inkeles (1990) concerned with whether dictatorships are good or bad for growth. Both studies conclude that it 
would be very difficult to argue for a strong effect either way. Some researchers nd mild results in one direction or the other while others nd the effects are ambiguous. Barro (1996a) nds some evidence that, while extreme dictatorships may harm growth, softer dictatorships may actually be good for growth.

For the present paper the important point about these works is that they concern average growth rates rather than some measure of the variability of the rates. Our theory does not predict that growth rates would be either higher or lower on average in dictatorships compared to democracies. But it does suggest that some dictatorships would grow very rapidly while others experience sharp decline. In other words, we would not be surprised to see dictatorships growing like democracies on average but would expect highly variable growth rates in dictatorships.

We tested this prediction using the Barro-Lee data set. ${ }^{26}$ For our limited purposes this means that we are using the Summers-Heston data (augmented by World Bank data when necessary) together with the annual ratings of political freedom carried out by Gastil (1970-1990). The Gastil concept of political freedom is mainly about the extent to which people are allowed to participate meaningfully in political processes. To score very well a country would need genuinely contested executive and legislative elections under fair conditions, regular shifts in power, freedom from foreign or military control and no major oppression of minority groups. The ratings are, of course, subjective in the nal analysis but they do generally accord with common sense.

We use data between 1970 and 1990 and calculate growth rates of real GDP per capita over both 5-year periods (1970-75, 75-80, 80-85, \& 85-90) and 10-year periods (1970-80 \& 80-90) for different exercises. We divide the countries into high political rights countries (Gastil index $<3$ ), middle rights countries $(3 \leq$ index $<5)$ and low rights countries $(5 \leq$ index $\leq 7)$. This is done by averaging for each country over the time period in question. Note that the political category of a country can vary across time periods.

Table 2 gives the percent of observations in each political category that experience negative growth according to various de nitions ranging from $<0 \%$ per

\footnotetext{
${ }^{26}$ The data together with a detailed description is available at http://www.nber.org/pub/barro.lee. Barro (1996a) carries out a growth regression exercise involving about 100 countries between 1960 and 1990, controlling for a large number of factors. His gure 4 (p. 15) shows the partial residuals of growth rates, controlling for everything except political freedom, plotted against political freedom. Inspection of this picture makes it fairly obvious that, consistent with our prediction, the variability of growth rates for low freedom countries is quite a bit larger than that for high freedom countries.
} 
year to $<-4 \%$ per year over a ten-year period. Thus, out of all high political rights observations $18.8 \%$ did not grow on average over a ten-year period, $11.8 \%$ declined faster than one percent per year, etc. The table clearly shows a much higher prevalence of negative growth experiences for low political rights countries than in high or middle rights countries. The results are the same if we use 5-year averages. North America is the only region of the world that does not contribute to the list of negative-growth-low-political-rights countries but the main contributors are Africa, the Caribbean and South America.

Table 2. \% by Political Category with Various Negative Growth Rates

\begin{tabular}{|l||l|l|l|l|l|}
\hline Political Rights & $g<0 \%$ & $g<-1 \%$ & $g<-2 \%$ & $g<-3 \%$ & $g<-4 \%$ \\
\hline High & 18.8 & 11.8 & 4.7 & 2.4 & 0 \\
\hline Middle & 31.1 & 20.0 & 11.1 & 6.7 & 4.4 \\
\hline Low & 45.8 & 32.2 & 17.8 & 9.3 & 5.9 \\
\hline
\end{tabular}

Now consider rapid growth as de ned by annual rates over 10-year periods averaging more than $4 \%, 5 \%, 6 \%$, and $7 \%$ as given in table 3 . Again we see that rapid growth is more frequent in dictatorships than democracies, although it is actually most common in the middle rights countries. The results are the same with 5-year averages. The list of high-growth-low-political-rights countries has representatives from every major region other than North America and the Caribbean, but the East Asian presence is especially strong. Perhaps surprisingly a fair number of African countries appear at least during certain time periods (e.g., Kenya, Lesotho, Nigeria, Tunisia).

Table 3. \% by Political Category with Various Rapid Growth Rates

\begin{tabular}{|l||l|l|l|l|}
\hline Political Rights & $g>4 \%$ & $g>5 \%$ & $g>6 \%$ & $g>7 \%$ \\
\hline High & 10.6 & 7.1 & 2.4 & 1.2 \\
\hline Middle & 22.2 & 15.6 & 6.7 & 2.2 \\
\hline Low & 17.8 & 9.3 & 5.1 & 2.5 \\
\hline
\end{tabular}

Since our theory predicts that dictatorship should be associated with both very high and also negative growth rates one would expect that the variance of the growth rate should be higher for low political rights countries than for high ones. Table 4 con rms this prediction. 
Table 4. Sample Variance in Growth Rates vs. Political Rights

\begin{tabular}{|l||l|l|l|}
\hline Time Periods & High & Middle & Low \\
\hline 5-year average & 6.0 & 13.2 & 15.3 \\
\hline 10-year average & 4.4 & 8.7 & 10.8 \\
\hline
\end{tabular}

Since political rights are positively correlated with income it is possible that table 4 is really just picking up a tendency for poor countries to have more variable growth rates than rich countries so we ran a regression to control for income. We divided the countries into ten GDP per capita classes, 0-2000, 2000-4000, ..., and $18,000-20,000$ (designated 1, 2, .., 10 respectively). Next we subdivided each income group into three subgroups for low, medium and high political rights (designated 1, 2, 3 respectively). Finally we calculated sample variances for growth rates over ve-year periods for each of these thirty groups. We got the following result in which the GDP variable is insigni cant and low political rights are associated with high variance in growth rates.

$$
\text { Variance of Growth Rates }=\underset{(2.8)}{51.6}+\underset{(.59)}{2.0}(G D P)-\underset{(-2.3)}{19.2}(\text { Political Rights })
$$

Finally, we focus on our bifurcation result that suggests that in dictatorships negative growth should be associated with low initial income and rapid growth with high initial income. Table 5 is consistent with this prediction. In the table the 1775 gure, for example, is the average of the initial GDPs per capita of all countries in the sample with growth rates above $4 \%$ per year for a 5 -year period.

Table 5. Average Initial Per Capita GDP: Dictatorships with Negative or Rapid Growth

\begin{tabular}{|l||l|l|}
\hline Growth Rate & 5 -year average & 10-year average \\
\hline$>4 \%$ & 1775 & 2116 \\
\hline$<-1 \%$ & 1664 & 1852 \\
\hline
\end{tabular}

\section{Conclusion}

The theory of dictatorship and growth presented in this paper provides an explanation for an important outstanding puzzle: why dictatorships display unusually high variability in growth rates. In the theory, dictators and elite groups who begin with poor political survival prospects are likely to embark on a downward spiral of 
plunder and decline. Unlikely to remain in power long, they consume what they can take rather than promote economic growth. Haiti, Iraq, Paraguay, Somalia, Yugoslavia and Zaire seem to $t$ this pattern of economic decline. In contrast, dictators and elite groups with better survival chances tend to choose especially rapid growth, above the social optimum, to further enhance their longevity. Keeping the economy booming tends to provide them with a long period in power during which they can expect to bene t. China, Ecuador, Indonesia, Lesotho, South Korea, and Tunisia seem to $\mathrm{t}$ this pattern of economic boom.

Indeed, choices made by dictatorships facing instability will often vary from choices predicted by standard growth models involving benevolent social planners. Good policy analysis should acknowledge the realities of dictatorships. Failure to do so may contribute to the mixed success of foreign aid programs (Delong, 1997, Hirschman, 1981). ${ }^{27}$ As one step toward explicit thinking about dictatorships, our paper provides a novel perspective on how dictatorships may respond to aid. In our framework decreasing corruption (lowering $\lambda$ ) actually yields lower growth, while decreasing a dictator s anticipated out-of-power utility, Umin, is good for growth. These results are due to the fact that the larger is the difference between a dictator s in-power and out-of-power utility, the greater is his determination to retain power and hence to encourage economic growth. This logic suggests that the international community focus more effort on reducing the comfort of dictators who have lost power, for example by freezing bank accounts and by prosecuting human rights violations, rather than on reducing the corruption of those who hold power. General Pinochet s recent experience in London may be good for growth in the developing world.

\section{Appendix: Solution of Optimal Policy Functions}

Optimal policy functions for the dictator and social planner were computed for a broad range of plausible parameter values. A value of capital of $\$ 10$ billion was chosen (without loss of generality) as the approximate value of a typical country s initial capital. A range from $\$ 0.1$ billion to $\$ 1$ trillion was then chosen as the set of values of capital for which results would be examined. Possible parameter values were chosen to yield values of production and other variables that match approximately with available empirical information, particularly around $\mathrm{K}=\$ 10$ billion. Table 1 shows the values considered. Every possible combination of these parameters was tried, yielding 432 sets of parameters.

\footnotetext{
${ }^{27}$ Wintrobe $(1990,1998)$ has already begun rethinking the relationship between dictatorships and democracies along these lines.
} 
For each set of parameter values, the dynamic programming problem was solved using a grid of possible values of capital. The grid was constrained to a nite set, which guarantees convergence for at least the social planner s optimal value function using Denardo s contraction mapping theorem. To ensure that the nite constraints of the grid had little impact on the results, the constraints were chosen to be two orders of magnitude below and above the range of results to be examined. The grid used thus ranged from $\$ 0.001$ billion to $\$ 100$ trillion, with 4,001 grid points equally spaced in the logarithm of $\mathrm{K}$ (thus yielding 500 grid steps per order of magnitude in $\mathrm{K}$ ).

The usual method to converge on an in nite-time-horizon optimal policy is to start by assuming that for any value of $\mathrm{K}$, society consumes all production in a hypothetical future period. The computation process then works backward in time, at each step computing for each value of $\mathrm{K}$ the optimal consumption given the discounted future value computed so far for next period $\mathrm{s} \mathrm{K}$ (which is uniquely determined by current $\mathrm{K}$ and consumption). The computation is declared to have converged on an in nite-time-horizon optimal policy when the change in the contemporaneous value function, between the current and previous time step, is less than $\varepsilon$. We used $\varepsilon=1.0 \times 10^{-5}$, with the steps equal to 1 year, and required that the convergence criterion be met for all points in the K-grid before convergence would be declared. ${ }^{28}$

Denardo s contraction mapping theorem guarantees convergence of the value function but not of the policy function, and the theorem does not apply to the more complex dictator s case, so we checked whether the solution converged for the policy function as well as the value function. ${ }^{29}$ For all cases the policy functions as well as the value functions converged. To ensure adequate convergence, an additional convergence criterion was required to hold before convergence was declared. For each point in the K-grid, the optimal fraction of output consumed had to differ by less than $\varepsilon$ from the value computed at the previous step, and this requirement had to hold for an additional 50 consecutive steps. The extra steps were required in case a small change in the value function at one step should induce a large change in the optimal policy function computed at a next step for

\footnotetext{
${ }^{28}$ At each step we solved for optimal policy to within a tolerance of $1.0 \times 10^{-6}$. Linear interpolation was used between points on the $K$-grid to nd values of functions of $K$ between points.

${ }^{29}$ Dynamic programming problems generally are solved for growth models with time-separable value functions. In the present problem, the dictator s value function is not time-separable: the dictator s decision in period $t$ affects the likelihood that he is in power in future periods, and hence affects his future value functions.
} 
some point on the K-grid; this sensitivity in computation was observed for some parameter values and the 50 additional steps appeared to be more than adequate to handle the sensitivity.

After solving for the optimal policy for a given set of parameters, it was necessary to carry out further tests. To isolate bifurcation points in economic growth for the dictator, we started with low and high values of $\mathrm{K}$ of $\$ 0.1$ billion and $\$ 1$ trillion respectively. The algorithm used initial working assumptions of negative growth at the bottom of this range and positive growth at the top of the range, and iterated by testing at the midpoint of the range to see whether growth was negative or positive. The search continued at each iteration by testing the midpoint between the highest point so far found to have negative growth and the lowest point so far found to have positive growth. The search was stopped when the difference between the values of $\mathrm{K}$ considered was less than 0.005 . If the search stopped within 0.005 of the minimum or maximum of the range tried, positive or negative growth respectively was declared to have occurred throughout the range. In any case a more intensive search was carried out above and below the apparent bifurcation point (or above the minimum or below the maximum if positive or negative growth was declared) to ensure that the growth patterns indeed involve a bifurcation with decline for values of $\mathrm{K}$ below the apparent bifurcation point and growth for values of $\mathrm{K}$ above the apparent bifurcation point (or growth or decline only if no bifurcation point was found). The search above (below) the point found was carried out by rst testing the value of $\mathrm{K}$ equal to 1.001 (0.999) times the value of $\mathrm{K}$ at the point, then successively increasing the distance away from the point by $10 \%$ per iteration until the full range from $\$ 0.1$ billion to $\$ 1$ trillion had been scrutinized.

\section{References}

Alesina, A. and Rodrik, D. (1994). Distributive politics and economic growth. Quarterly Journal of Economics, vol. 109, pp. 465-90.

Alesina, A. and Tabellini, G. (1990). A positive theory of scal de cit and government debt. Review of Economic Studies, vol. 57, pp. 403-14.

Azariadis, C. and Drazen, A. (1990). Threshold externalities in economic development. Quarterly Review of Economics, vol. 105, pp. 501-26.

Bardhan, P. (1997). Corruption and development: a review of issues. Journal of Economic Literature, vol. 35, no. 3, pp. 1320-46. 
Barro, R. (1996a). Democracy and growth. Journal of Economic Growth, vol. 1, pp. 1-27.

Barro, R. (1996b). Getting It Right, Cambridge: M.I.T. Press.

Bertocchi, G. and Spagat, M. (2000). The politics of co-optation. Mimeo, Royal Holloway College, University of London.

Bertocchi, G. and Spagat, M. (1997). Structural uncertainty and subsidy removal for economies in transition. European Economic Review, vol. 41, pp. 1709-33.

Clague, C., Keefer, P., Knack, S. and Olson, M. (1996). Property and contract rights in autocracies and democracies. Journal of Economic Growth, vol. 1, pp. 243-76.

De la Balze, F. (1995). Remaking the Argentine Economy, New York: Council of Foreign Relations Press.

De Long, J. B. (1997). Slouching Towards Utopia?: The Economic History of the Twentieth Century, published on the internet at http://www.j-bradforddelong.net/TCEH/Slouch_title.html.

Dewatripont, M. and Roland, G. (1992). Economic reform and dynamic political constraints. Review of Economic Studies, vol. 59, October, pp. 703-30.

Fan, S., Overland J. and Spagat, M. (1999). Human capital, growth and inequality in Russia. Journal of Comparative Economics, vol. 27, pp. 618-43.

Gastil, R. (1990). The comparative survey of freedom: experiences and suggestions. Studies in Comparative Development, vol. 25, pp. 25-50.

Gastil, R. (various years). Freedom in the World, New York: Freedom House and others.

Grossman, H. and Noh, S. (1990). A theory of kleptocracy with probabilistic survival and reputation. Economics and Politics, vol. 2, pp. 157-71.

Grossman, H. and Noh, S. (1994). Proprietary public nance and economic welfare. Journal of Public Economics, vol. 53, pp. 187-204.

Hirschman, A. O. (1981). Essays in Trespassing: Economics to Politics and Beyond, Cambridge: Cambridge University Press.

Lucas, R. (1988). On the mechanics of economic development. Journal of Monetary Economics, vol. 22, no. 1, pp. 3-42. 
Mankiw, G., Romer, D. and Weil, D. (1992). A contribution to the empirics of economic growth. Quarterly Journal of Economics, vol. 107, pp. 407-37.

Marcouiller, D. and Young, L. (1995). The black hole of graft: the predatory state and the informal economy. American Economic Review, vol. 85, pp. 630-46.

McGuire, M. and Olson, M. (1996). The economics of autocracy and majority rule. Journal of Economic Literature, vol. 34, pp. 72-96.

Moorehead, A. (1958). The Russian Revolution, New York: Time Inc.

Murphy, K., Shleifer, A. and Vishny, R. (1989). Industrialization and the big push. Journal of Political Economy, vol. 97, pp. 1003-26.

Olson, M. (1963). Rapid growth as a destabilizing force. Journal of Economic History, vol. 23, pp. 529-52.

Olson, M. (1991). Autocracy, democracy and prosperity. In (R. Zeckhauser, ed.) Strategy and Choice, Cambridge: MIT Press, pp. 131-57.

Olson, M. (1993). Dictatorship, democracy, and development. American Political Science Review, vol. 87, no. 3, pp. 567-75.

Olson, M. (2000). Power and Prosperity, New York: Basic Books.

Overland, J. and Spagat, M. (1996). Human capital and the economic transformation of Russia. Transition, vol. 2, no. 13, pp. 12-15.

Perotti, R. (1993). Political equilibrium, income distribution, and growth. Review of Economic Studies, vol. 60, pp. 755-76.

Persson, T. and Tabellini, G. (1994). Is inequality harmful for growth? American Economic Review, vol. 84, pp. 600-621.

Przeworski, A. and Limongi, F. (1993). Political regimes and economic growth. Journal of Economic Perspectives, vol. 7, pp. 51-69.

Przeworski, A. and Limongi, F. (1997). Modernization: theories and facts. World Politics, vol. 49, pp. 155-83.

Przeworski, A., Alvarez, M., Ceibub, J. and Limongi, F. (1996). What makes democracies endure? Journal of Democracy, vol. 7, pp. 39-55.

Roberts, B. and Rodriguez, A. (1997). Economic growth under a self-interested central planner and transition to a market economy. Journal of Comparative Economics, vol. 24, pp. 121-39.

Robinson, J. (1998). When is a state predatory? Mimeo. University of California, Berkeley. 
Rodrik, D. (1996). Understanding economic policy reform. Journal of Economic Literature, vol. 34, no. 1, pp. 9-41.

Sah, R. (1991). Fallibility in human organizations and political systems. Journal of Economic Perspectives, vol. 5, pp. 67-88.

Sachs, J. and Warner, A. (1995). Economic reform and the process of global integration. Brookings Papers on Economic Activity, pp. 1-95.

Sirowy, L. and Inkeles, A. (1990). The effects of democracy on economic growth and inequality: a review. Studies in Comparative International Development, vol. 25, pp. 126-57.

Spagat, M. (1999). Nobody expects the Spanish Inquisition: the dynamics of repressive dictatorships. Mimeo, Royal Holloway College, University of London.

Wintrobe, R. (1990). The tinpot and the totalitarian: an economic theory of dictatorship. American Political Science Review, vol. 84, pp. 849-72.

Wintrobe, R. (1998). The Political Economy of Dictatorship, Cambridge: Cambridge University Press. 
Table 1. Parameter Grid for Computations

\begin{tabular}{|c|c|c|c|}
\hline Parameter & Used for & Units & Values \\
\hline$\alpha$ & Production & none & 0.3333 \\
\hline$\theta$ & Catastrophe & $1 /($ billion $\$)$ & $\ln (.75), \ln (.9), \ln (.97)^{*}$ \\
\hline$\eta$ & Catastrophe & none & $\ln q_{1}-10 \theta$, with $q_{1}=.05, .15, .3, .5^{* *}$ \\
\hline$\delta$ & Depreciation & $1 /$ years & $.05, .1$ \\
\hline$\sigma$ & Utility function & none & $0.5,1,1.5$ \\
\hline$\lambda$ & Appropriation & none & $\begin{array}{l}\text { normalized to } 1 \text { (but variations of } U_{\min } \text { are } \\
\text { analogous) }\end{array}$ \\
\hline$U_{\text {min }}$ & Utility function & utiles & $\begin{array}{l}=U\left(a_{1} a_{2} F\left(K_{0}=10\right)\right) \text {, where } \mathrm{a}_{1} \text { is a typical } \\
\text { consumption fraction and } \mathrm{a}_{2} \text { is a multiplier } \\
\text { to the dictator's consumption when out of } \\
\text { power relative to when in power; } a_{1} a_{2}= \\
.001, .01, .05\end{array}$ \\
\hline$\beta$ & Discount factor & 1/years & $.90, .95$ \\
\hline$\rho$ & Mobile capital & 1/years & .02 \\
\hline$v$ & Production & $\begin{array}{l}\text { billion } \\
\text { \$/year }\end{array}$ & $\begin{array}{l}{\left[\frac{3(G+\delta)}{\alpha \gamma}\right]^{\alpha}\left[\frac{\rho}{1-\alpha}\right]^{1-\alpha} \text {, where } G \text { is a }} \\
\text { typical national capital growth rate when } \\
1 / 3 \text { of output is invested, } G=.03\end{array}$ \\
\hline
\end{tabular}

*The values for $\theta$ imply that if $\mathrm{K}$ increases from its initial value of 10 to a value of 11 billion dollars one year later, the catastrophe probability falls by a multiple of $.75 / .9 / .97$, i.e. by $25 \% / 10 \% / 3 \%$, over that one-year period.

**The values of $\eta$ are computed after finding the value for $\theta$, and are chosen such that $\mathrm{q}_{1}$, the probability of catastrophe at the end of the dictator's first year in power, is $.05, .15, .3$, or .5 . Note that $\mathrm{F}\left(\mathrm{K}_{0}=10\right)$ in the expression above can be replaced with $v \alpha\left(\frac{v(1-\alpha)}{\rho}\right)^{\frac{1-\alpha}{\alpha}} 10$. 


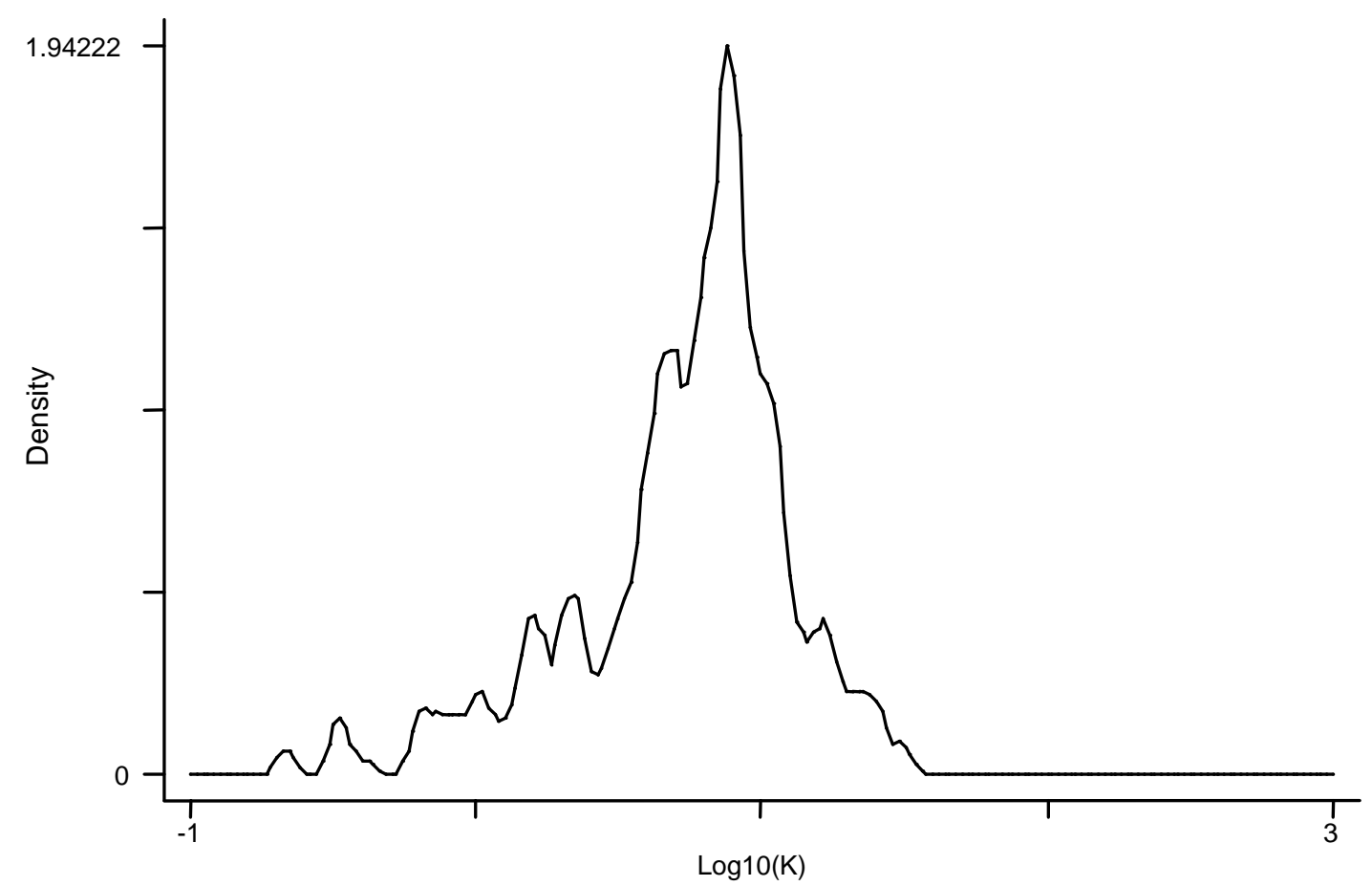

Figure 1. Values of $\mathrm{K}$ at Which Bifurcation Occurs 


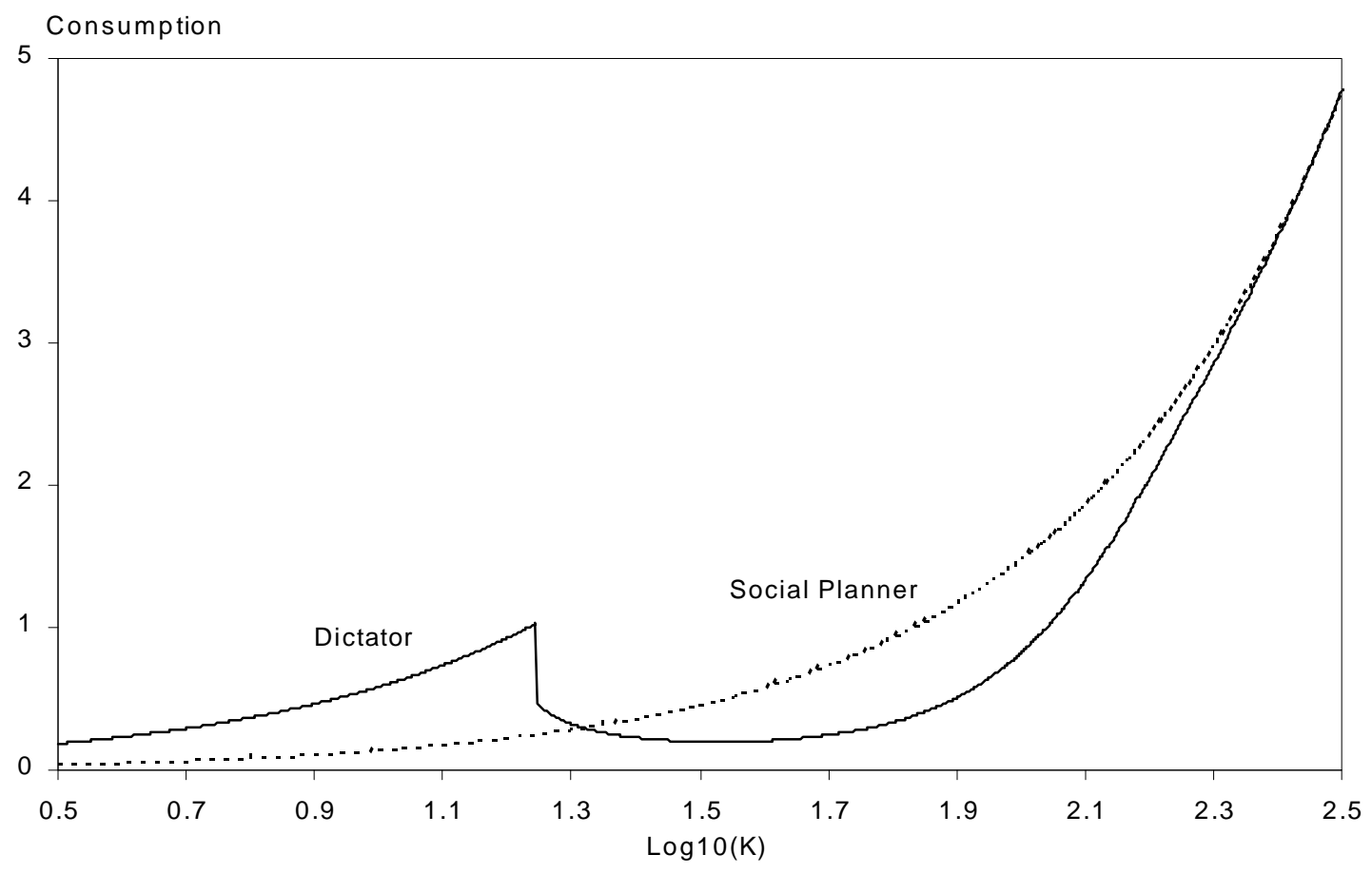

Figure 2. Typical Dictator's and Planner's Policy Functions (\$billion of consumption and capital) 


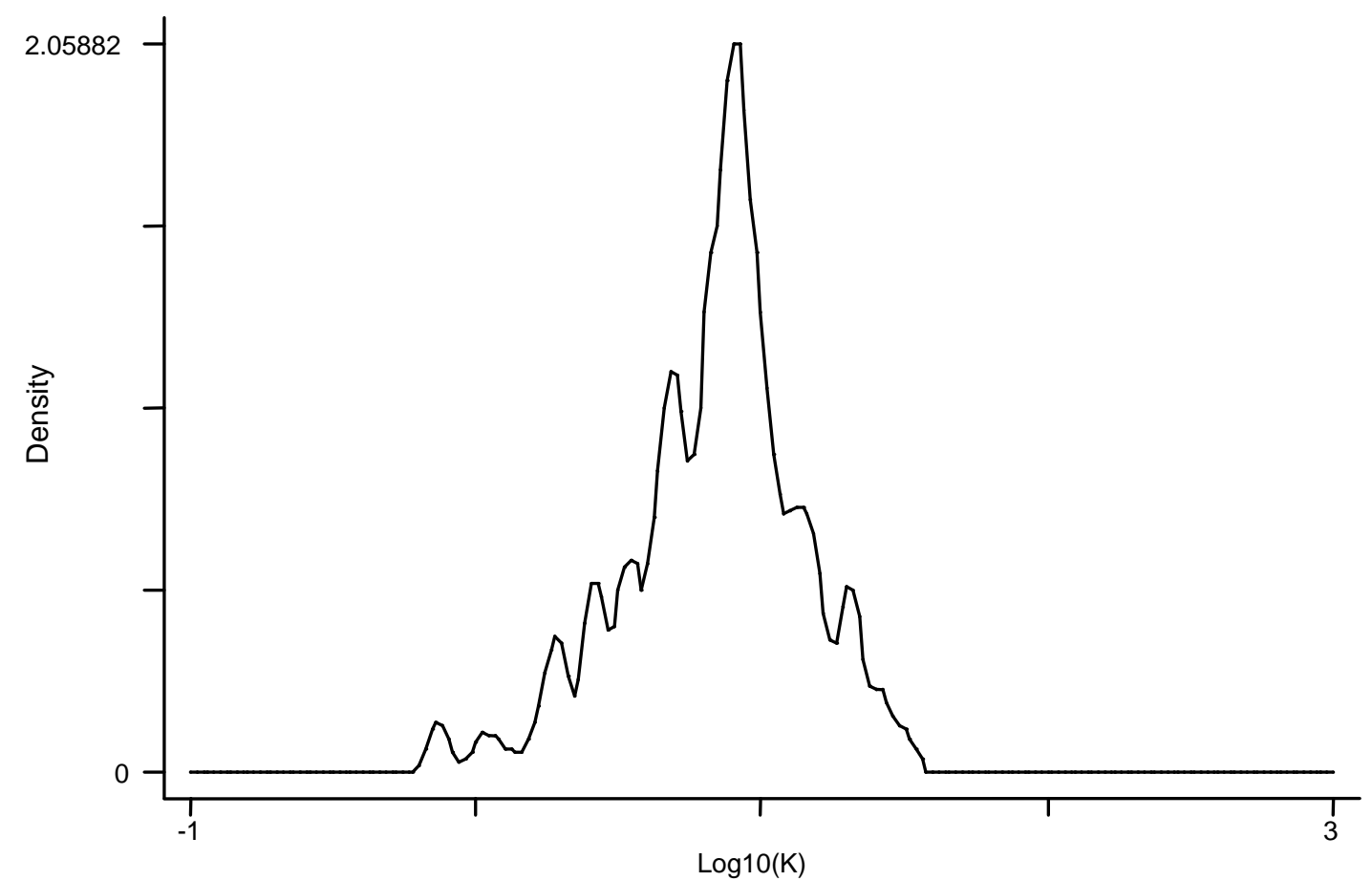

Figure 3. Values of $\mathrm{K}$ at Which Cut-Through Occurs 


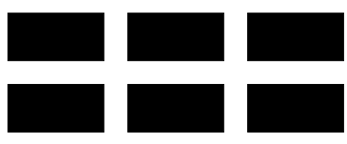

THE WILLIAM DAVIDSON INSTITUTE

AT THE UNIVERSITY OF MICHIGAN BUSINESSSCHOOL

\section{DAVIDSON INSTITUTE WORKING PAPER SERIES}

Working Papers are available at: www.wdi.bus.umich.edu

CURRENT AS OF $12 / 20 / 00$

\begin{tabular}{|c|c|c|}
\hline Publication & Authors & Date \\
\hline No. 354 Political Instability and Growth in Dictatorships & $\begin{array}{l}\text { Jody Overland, Kenneth L. } \\
\text { Simons and Michael Spagat }\end{array}$ & Nov. 2000 \\
\hline No. 353 Disintegration and Trade & Jarko Fidrmuc and Jan Fidrmuc & Nov. 2000 \\
\hline $\begin{array}{l}\text { No. } 352 \text { Social Capital and Entrepreneurial Performance in Russia: A } \\
\text { Panel Study }\end{array}$ & Bat Batjargal & Dec. 2000 \\
\hline $\begin{array}{l}\text { No. 351 Entrepreneurial Versatility, Resources and Firm Performance in } \\
\text { Russia: A Panel Study }\end{array}$ & Bat Batjargal & Dec. 2000 \\
\hline $\begin{array}{l}\text { No. } 350 \text { The Dynamics of Entrepreneurial Networks in a Transitional } \\
\text { Economy: The Case of Russia }\end{array}$ & Bat Batjargal & Dec. 2000 \\
\hline $\begin{array}{l}\text { No. } 349 \text { R\&D and Technology Spillovers via FDI: Innovation and } \\
\text { Absorptive Capacity }\end{array}$ & Yuko Kinoshita & Nov. 2000 \\
\hline $\begin{array}{l}\text { No. } 348 \text { Microeconomic aspects of Economic Growth in Eastern } \\
\text { Europe and the Former Soviet Union, 1950-2000 }\end{array}$ & Sergei Guriev and Barry W. Ickes & Nov. 2000 \\
\hline $\begin{array}{l}\text { No. } 347 \text { Effective versus Statutory Taxation: Measuring Effective Tax } \\
\text { Administration in Transition Economies }\end{array}$ & $\begin{array}{l}\text { Mark E. Schaffer and Gerard } \\
\text { Turley }\end{array}$ & Nov. 2000 \\
\hline $\begin{array}{l}\text { No. } 346 \text { Objectives and Constraints of Entrepreneurs: Evidence from } \\
\text { Small and Medium Size Enterprises in Russia and Bulgaria }\end{array}$ & $\begin{array}{l}\text { Francesca Pissarides, Miroslav } \\
\text { Singer and Jan Svejnar }\end{array}$ & 2000 \\
\hline No. 345 Corruption and Anticorruption in the Czech Republic & $\begin{array}{l}\text { Lubomír Lízal and Evžen } \\
\text { Kočenda }\end{array}$ & 2000 \\
\hline No. 344 The Effects of Dir & onings & Oct. 2000 \\
\hline No. 343 On the Identification of Relative Wage Rigidity L & . Puhani & Oct. 2000 \\
\hline $\begin{array}{l}\text { No. } 342 \text { The Determinants of Foreign Direct Investment in Transition } \\
\text { Economies }\end{array}$ & Alan A. Bevan and Saul Estrin & Oct. 2000 \\
\hline No. 341 The Global Spread of Stock Exchanges, 1980-1998 & Klaus Weber and $\mathrm{C}$ & Nov. 2000 \\
\hline $\begin{array}{l}\text { No. } 340 \text { The Costs and Benefits of Euro-isation in Central-Eastern } \\
\text { Europe Before or Instead of EMU Membership }\end{array}$ & D. Mario Nuti & Oct. 2000 \\
\hline No. 339 Debt Overhang and Barter in Russia & $\begin{array}{l}\text { Sergei Guriev, Igor Makarov and } \\
\text { Mathilde Maurel }\end{array}$ & Sept. 2000 \\
\hline $\begin{array}{l}\text { No. } 338 \text { Firm Performance and the Political Economy of Corporate } \\
\text { Governance: Survey Evidence for Bulgaria, Hungary, Slovakia and } \\
\text { Slovenia }\end{array}$ & $\begin{array}{l}\text { Patrick Paul Walsh and Ciara } \\
\text { Whela }\end{array}$ & July 2000 \\
\hline No. 337 Investment and Instability & $\begin{array}{l}\text { Nauro F. Campos and Jeffrey B. } \\
\text { Nugent }\end{array}$ & May 2000 \\
\hline $\begin{array}{l}\text { No. } 336 \text { The Evolution of the Insurance Sector in Central and } \\
\text { Eastern Europe and the former Soviet Union }\end{array}$ & Robert B.K. Pye & Aug. 2000 \\
\hline $\begin{array}{l}\text { No. } 335 \text { Institutional Technology and the Chains of Trust: Capital } \\
\text { Markets and Privatization in Russia and the Czech Republic }\end{array}$ & Bruce Kogut and Andrew Spicer & Aug. 2000 \\
\hline No. 334 The Evolution of Market Integration in Russia & $\begin{array}{l}\text { Daniel Berkowitz and David N. } \\
\text { DeJong }\end{array}$ & Aug. 2000 \\
\hline No. 333 Efficiency and Market Share in Hungarian Corporate Sector & László Halpern and Gábor Körösi & July 2000 \\
\hline No. 332 Search-Money-and-Barter Models of Financial Stabilization & $\begin{array}{l}\text { S.I. Boyarchenko and S.Z. } \\
\text { Levendorskii }\end{array}$ & July 2000 \\
\hline $\begin{array}{l}\text { No. } 331 \text { Worker Training in a Restructuring Economy: Evidence from } \\
\text { the Russian Transition }\end{array}$ & $\begin{array}{l}\text { Mark C. Berger, John S. Earle } \\
\text { and Klara Z. Sabirianova }\end{array}$ & Aug. 2000 \\
\hline $\begin{array}{l}\text { No. } 330 \text { Economic Development in Palanpur 1957-1993: A Sort of } \\
\text { Growth }\end{array}$ & Peter Lanjouw & Aug. 2000 \\
\hline
\end{tabular}




\begin{tabular}{|c|c|c|}
\hline $\begin{array}{l}\text { No. } 329 \text { Trust, Organizational Controls, Knowledge Acquisition from } \\
\text { the Foreign Parents, and Performance in Vietnamese International Joint } \\
\text { Ventures }\end{array}$ & $\begin{array}{l}\text { Marjorie A. Lyles, Le Dang } \\
\text { Doanh, and Jeffrey Q. Barden }\end{array}$ & June 2000 \\
\hline $\begin{array}{l}\text { No. } 328 \text { Comparative Advertising in the Global Marketplace: The } \\
\text { Effects of Cultural Orientation on Communication }\end{array}$ & $\begin{array}{l}\text { Zeynep Gürhan-Canli and } \\
\text { Durairaj Maheswaran }\end{array}$ & Aug. 2000 \\
\hline No. 327 Post Privatization Enterprise Restructuring & Morris Bornstein & July 2000 \\
\hline No. 326 Who is Afraid of Political Instability? & $\begin{array}{l}\text { Nauro F. Campos and Jeffrey B. } \\
\text { Nugent }\end{array}$ & July 2000 \\
\hline No. 325 Business Groups, the Financial Market and Modernization & Raja Kali & June 2000 \\
\hline $\begin{array}{l}\text { No. } 324 \text { Restructuring with What Success? A Case Study of Russian } \\
\text { Firms }\end{array}$ & Susan Linz & July 2000 \\
\hline $\begin{array}{l}\text { No. } 323 \text { Priorities and Sequencing in Privatization: Theory and } \\
\text { Evidence from the Czech Republic }\end{array}$ & $\begin{array}{l}\text { Nandini Gupta, John C. Ham and } \\
\text { Jan Svejnar }\end{array}$ & May 2000 \\
\hline $\begin{array}{l}\text { No. } 322 \text { Liquidity, Volatility, and Equity Trading Costs Across } \\
\text { Countries and Over Time }\end{array}$ & $\begin{array}{l}\text { Ian Domowitz, Jack Glen and } \\
\text { Ananth Madhavan }\end{array}$ & Mar. 2000 \\
\hline $\begin{array}{l}\text { No. } 321 \text { Equilibrium Wage Arrears: A Theoretical and Empirical } \\
\text { Analysis of Institutional Lock-In }\end{array}$ & $\begin{array}{l}\text { John S. Earle and Klara Z. } \\
\text { Sabirianova }\end{array}$ & Oct. 2000 \\
\hline No. 320 Rethinking Marketing Programs for Emerging Markets & $\begin{array}{l}\text { ar and Amitava } \\
\text { hyay }\end{array}$ & June 2000 \\
\hline $\begin{array}{l}\text { ance and Low Equilibria in Transition Economies: } \\
\text { ons }\end{array}$ & $\begin{array}{l}\text { Daniel Daianu and Radu } \\
\text { Vranceanu }\end{array}$ & June 2000 \\
\hline $\begin{array}{l}\text { No. } 318 \text { Some Econometric Evidence on the Effectiveness of Active } \\
\text { Labour Market Programmes in East Germany }\end{array}$ & $\begin{array}{l}\text { Martin Eichler and Michael } \\
\text { Lechner }\end{array}$ & June 2000 \\
\hline No. 317 A Model of Russia's "Virtual Economy" & cson and B.W Ickes & May 2000 \\
\hline $\begin{array}{l}\text { No. } 316 \text { Financial Institutions, Financial Contagion, and Financial } \\
\text { Crises }\end{array}$ & $\begin{array}{l}\text { Haizhou Huang and Chenggang } \\
\mathrm{Xu}\end{array}$ & Mar. 2000 \\
\hline $\begin{array}{l}\text { No. } 315 \text { Privatization versus Regulation in Developing Economies: The } \\
\text { Case of West African Banks }\end{array}$ & $\begin{array}{l}\text { Jean Paul Azam, Bruno Biais, and } \\
\text { Magueye Dia }\end{array}$ & 2000 \\
\hline $\begin{array}{l}\text { No. } 314 \text { Is Life More Risky in the Open? Household Risk-Coping and } \\
\text { the Opening of China's Labor Markets }\end{array}$ & John Giles & Apr. 2000 \\
\hline $\begin{array}{l}\text { No. } 313 \text { Networks, Migration and Investment: Insiders and Outsiders in } \\
\text { Tirupur's Production Cluster }\end{array}$ & t Banerjee and Kaivan & Mar. 2000 \\
\hline $\begin{array}{l}\text { No. } 312 \text { Computational Analysis of the Impact on India of the Uruguay } \\
\text { Round and the Forthcoming WTO Trade Negotiations }\end{array}$ & $\begin{array}{l}\text { Rajesh Chadha, Drusilla K. } \\
\text { Brown, Alan V. Deardorff and } \\
\text { Robert M. Stern }\end{array}$ & Mar. 2000 \\
\hline No. 311 Subsidized Jobs for Un & Jan. C. van Ours & May 2000 \\
\hline No. 310 Determinants of Managerial Pay in the Czech Republic & $\begin{array}{l}\text { Tor Eriksson, Jaromir Gottvald } \\
\text { and Pavel Mrazek }\end{array}$ & May 2000 \\
\hline $\begin{array}{l}\text { No. } 309 \text { The Great Human Capital Reallocation: An Empirical Analysis } \\
\text { of Occupational Mobility in Transitional Russia }\end{array}$ & Klara Z. Sabirianova & Oct. 2000 \\
\hline No. 308 Economic Development, Legality, and the Transplant Effect & $\begin{array}{l}\text { Daniel Berkowitz, Katharina } \\
\text { Pistor, and Jean-Francois Richard }\end{array}$ & Feb. 2000 \\
\hline $\begin{array}{l}\text { No. } 307 \text { Community Participation, Teacher Effort, and Educational } \\
\text { Outcome: The Case of El Salvador's EDUCO Program }\end{array}$ & Yasuyuki Sawada & Nov. 1999 \\
\hline No. 306 Gender Wage Gap and Segregation in Late Transition & Jurajda & May 2000 \\
\hline $\begin{array}{l}\text { No. } 305 \text { The Gender Pay Gap in the Transition from Communism: } \\
\text { Some Empirical Evidence }\end{array}$ & Andrew Newell and Barry Reilly & May 2000 \\
\hline No. 304 Post-Unification Wage Growth in East Germany & Jennifer Hunt & Nov. 1998 \\
\hline $\begin{array}{l}\text { No. } 303 \text { How Does Privatization Affect Workers? The Case of the } \\
\text { Russian Mass Privatization Program }\end{array}$ & Elizabeth Brainerd & May 2000 \\
\hline $\begin{array}{l}\text { No. } 302 \text { Liability for Past Environmental Contamination and } \\
\text { Privatization }\end{array}$ & Dietrich Earnhart & Mar. 2000 \\
\hline No. 301 Varieties, Jobs and EU Enlargement & $\begin{array}{l}\text { Tito Boeri and Joaquim Oliveira } \\
\text { Martins }\end{array}$ & May 2000 \\
\hline No. 300 Employer Size Effects in Russia & Todd Idson & Apr. 2000 \\
\hline
\end{tabular}




\begin{tabular}{|c|c|c|}
\hline $\begin{array}{l}\text { No. } 299 \text { Information Complements, Substitutes, and Strategic Product } \\
\text { Design }\end{array}$ & $\begin{array}{l}\text { Geoffrey G. Parker and Marshall } \\
\text { W. Van Alstyne }\end{array}$ & Mar. 2000 \\
\hline $\begin{array}{l}\text { No. } 298 \text { Markets, Human Capital, and Inequality: Evidence from Rural } \\
\text { China }\end{array}$ & $\begin{array}{l}\text { Dwayne Benjamin, Loren Brandt, } \\
\text { Paul Glewwe, and Li Guo }\end{array}$ & May 2000 \\
\hline No. 297 Corporate Governance in the Asian Financial Crisis & $\begin{array}{l}\text { Simon Johnson, Peter Boone, } \\
\text { Alasdair Breach, and Eric } \\
\text { Friedman }\end{array}$ & Nov. 1999 \\
\hline No. 296 Competition and Firm Performance: Lessons from Russia & J. David Brown and John S. Earle & Mar. 2000 \\
\hline No. 295 Wage Determination in Russia: An Econometric Investigation & $\begin{array}{l}\text { Peter J. Luke and Mark E. } \\
\text { Schaffer }\end{array}$ & Mar. 2000 \\
\hline $\begin{array}{l}\text { No. 294: Can Banks Promote Enterprise Restructuring?: Evidence From } \\
\text { a Polish Bank's Experience }\end{array}$ & John P. Bonin and Bozena Leven & Mar. 2000 \\
\hline No. 293: Why do Governments Sell Privatised Companies Abroad? & $\begin{array}{l}\text { Bernardo Bortolotti, Marcella } \\
\text { Fantini and Carlo Scarpa }\end{array}$ & Mar. 2000 \\
\hline $\begin{array}{l}\text { No. 292: Going Public in Poland: Case-by-Case Privatizations, Mass } \\
\text { Privatization and Private Sector Initial Public Offerings }\end{array}$ & Wolfgang Aussenegg & Dec. 1999 \\
\hline $\begin{array}{l}\text { No. 291: Institutional Technology and the Chains of Trust: Capital } \\
\text { Markets and Privatization in Russia and the Czech Republic }\end{array}$ & Bruce Kogut and Andrew Spicer & Mar. 1999 \\
\hline No. 290: Banking Crises and Bank Rescues: The Effect of Reputation & Jenny Corbett and & Jan. 2000 \\
\hline $\begin{array}{l}\text { No. 289: Do Active Labor Market Policies Help Unemployed Workers } \\
\text { to Find and Keep Regular Jobs? }\end{array}$ & Jan C. van Ours & Feb. 2000 \\
\hline No. 288: Consumption Patterns of the New Elite in Zimbabwe & Russell Belk & Feb. 2000 \\
\hline $\begin{array}{l}\text { No. 287: Barter in Transition Economies: Competing Explanations } \\
\text { Confront Ukranian Data }\end{array}$ & $\begin{array}{l}\text { Dalia Marin, Daniel Kaufmann } \\
\text { and Bogdan Gorochowskij }\end{array}$ & Jan. 2000 \\
\hline $\begin{array}{l}\text { No. 286: The Quest for Pension Reform: Poland's Security through } \\
\text { Diversity }\end{array}$ & $\begin{array}{l}\text { Marek Góra and Michael } \\
\text { Rutkowski }\end{array}$ & Jan. 2000 \\
\hline No. 285: Disorganization and Financial Collapse & $\begin{array}{l}\text { arin and Monika } \\
\text { r }\end{array}$ & Oct. 1999 \\
\hline No. 284: Coordinating Changes in M-for & $\begin{array}{l}\text { Yingyi Qian, Gérard Roland and } \\
\text { Chenggang Xu }\end{array}$ & May 1999 \\
\hline $\begin{array}{l}\text { No. 283: Why Russian Workers Do Not Move: Attachment of Workers } \\
\text { Through In-Kind Payments }\end{array}$ & Guido Friebel and Sergei Guriev & 1999 \\
\hline No. 282: Lessons From Fiascos in Russian Corporate Governance & $\begin{array}{l}\text { Merritt B. Fox and } \\
\text { Heller }\end{array}$ & 1999 \\
\hline $\begin{array}{l}\text { No. 281: Income Distribution and Price Controls: Targeting a Social } \\
\text { Safety Net During Economic Transition }\end{array}$ & $\begin{array}{l}\text { Michael Alexeev and James } \\
\text { Leitzel }\end{array}$ & Mar. 1999 \\
\hline $\begin{array}{l}\text { No. 280: Starting Positions, Reform Speed, and Economic Outcomes in } \\
\text { Transitioning Economies }\end{array}$ & William Hallagan and Zhang Jun & Jan. 2000 \\
\hline No. 279 : The Value of Prominent Directors & o Miwa \& J. Mark & Oct. 1999 \\
\hline No. 278: The & János Kornai & Apr. 1998 \\
\hline $\begin{array}{l}\text { No. 277: The Developmental Consequences of Foreign Direct } \\
\text { Investment in the Transition from Socialism to Capitalism: The } \\
\text { Performance of Foreign Owned Firms in Hungary }\end{array}$ & Lawrence Peter King & Sept. 1999 \\
\hline $\begin{array}{l}\text { No. 276: Stability and Disorder: An Evolutionary Analysis of Russia's } \\
\text { Virtual Economy }\end{array}$ & $\begin{array}{l}\text { Clifford Gaddy and Barry W. } \\
\text { Ickes }\end{array}$ & Nov. 1999 \\
\hline $\begin{array}{l}\text { No. 275: Limiting Government Predation Through Anonymous } \\
\text { Banking: A Theory with Evidence from China. }\end{array}$ & $\begin{array}{l}\text { Chong-En Bai, David D. Li, } \\
\text { Yingyi Qian and Yijiang Wang }\end{array}$ & July 1999 \\
\hline with Labour Supply & Tito Boeri & Dec. 1999 \\
\hline $\begin{array}{l}\text { No. 273: Sectoral Restructuring and Labor Mobility: A Comparative } \\
\text { Look at the Czech Republic }\end{array}$ & Vit Sorm and Katherine Terrell & Nov. 1999 \\
\hline $\begin{array}{l}\text { No. 272: Published in: Journal of Comparative Economics "Returns to } \\
\text { Human Capital Under the Communist Wage Grid and During the } \\
\text { Transition to a Market Economy" Vol. 27, pp. 33-60 } 1999 .\end{array}$ & $\begin{array}{l}\text { Daniel Munich, Jan Svejnar and } \\
\text { Katherine Terrell }\end{array}$ & Oct. 1999 \\
\hline $\begin{array}{l}\text { No. 271: Barter in Russia: Liquidity Shortage Versus Lack of } \\
\text { Restructuring }\end{array}$ & $\begin{array}{l}\text { Sophie Brana and Mathilde } \\
\text { Maurel }\end{array}$ & June 1999 \\
\hline
\end{tabular}


Davidson Institute Working Papers are available at: www.wdi.bus.umich.edu

\begin{tabular}{|c|c|c|}
\hline $\begin{array}{l}\text { No. 270: Tests for Efficient Financial Intermediation with Application to } \\
\text { China }\end{array}$ & Albert Park and Kaja Sehrt & Mar. 1999 \\
\hline $\begin{array}{l}\text { No. 269a: Russian Privatization and Corporate Governance: What Went } \\
\text { Wrong? }\end{array}$ & $\begin{array}{l}\text { Bernard Black, Reinier Kraakman } \\
\text { and Anna Tarassova }\end{array}$ & May 2000 \\
\hline $\begin{array}{l}\text { No. 269: Russian Privatization and Corporate Governance: What Went } \\
\text { Wrong? }\end{array}$ & $\begin{array}{l}\text { Bernard Black, Reinier Kraakman } \\
\text { and Anna Tarassova }\end{array}$ & Sept. 1999 \\
\hline No. 268: Are Russians Really Ready for Capitalism? & Susan Linz & Sept. 1999 \\
\hline No. 267: Do Stock Markets Promote Economic Growth? & $\begin{array}{l}\text { Randall K. Filer, Jan Hanousek } \\
\text { and Nauro Campos }\end{array}$ & Sept. 1999 \\
\hline $\begin{array}{l}\text { No. 266: Objectivity, Proximity and Adaptability in Corporate } \\
\text { Governance }\end{array}$ & $\begin{array}{l}\text { Arnoud W.A Boot and Jonathan } \\
\text { R. Macey }\end{array}$ & Sept. 1999 \\
\hline $\begin{array}{l}\text { No. 265: When the Future is not What it Used to Be: Lessons from the } \\
\text { Western European Experience to Forecasting Education and Training in } \\
\text { Transitional Economies }\end{array}$ & $\begin{array}{l}\text { Nauro F. Campos, Gerard } \\
\text { Hughes, Stepan Jurajda, and } \\
\text { Daniel Munich }\end{array}$ & 1999 \\
\hline $\begin{array}{l}\text { No. 264: The Institutional Foundation of Foreign-Invested Enterprises } \\
\text { (FIEs) in China }\end{array}$ & Yasheng Huang & 1999 \\
\hline $\begin{array}{l}\text { No. 263: The Changing Corporate Governance Paradigm: Implications } \\
\text { for Transition and Developing Countries }\end{array}$ & $\lg$ & 999 \\
\hline No. 262: Law & $\begin{array}{l}\text { Gerard Rola } \\
\text { Verdier }\end{array}$ & May 1999 \\
\hline $\begin{array}{l}\text { No. 261: Soft Budget Constraints, Pecuniary Externality, } \\
\text { Track System }\end{array}$ & Jiah & June 2000 \\
\hline $\begin{array}{l}\text { No. 260: Missing Market in Labor Quality: The Role of Quality Markets } \\
\text { in Transition }\end{array}$ & $\mathrm{Ga}$ & July 1999 \\
\hline $\begin{array}{l}\text { No. 259: Do Corporate Global Environmental Standards in Emerging } \\
\text { Markets Create or Destroy Market Value }\end{array}$ & 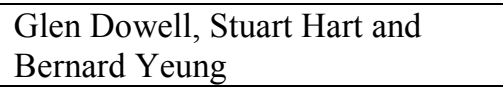 & June 1999 \\
\hline flows from Unemployment & & June 1999 \\
\hline $\begin{array}{l}\text { No. 257: Owne } \\
\text { Inefficient? }\end{array}$ & $\begin{array}{l}\mathrm{A} \\
\mathrm{H}_{2}\end{array}$ & June 1999 \\
\hline $\begin{array}{l}\text { No. 256: Taxation and Evasion in the Presence of Exortion by } \\
\text { Organized Crime }\end{array}$ & oa & 1999 \\
\hline No. 255: Revisiting Hungary’s Bankruptcy Episode & Mark E. & 999 \\
\hline No. 254: FD & & 999 \\
\hline $\begin{array}{l}\text { No. 253: Th } \\
\text { Done }\end{array}$ & Thye & 999 \\
\hline No. 252: Organizational Law as Asset Partitioning & y Hansmann and Reinier & 1999 \\
\hline $\begin{array}{l}\text { No. 251: Con } \\
\text { the Case of th }\end{array}$ & $\begin{array}{l}\text { ct E. M. Steenkamp } \\
\text { M. Burgess }\end{array}$ & 1999 \\
\hline $\begin{array}{l}\text { No. 250: Property Rights Formation and the Organization of Exchange } \\
\text { and Production in Rural China }\end{array}$ & $\mathrm{Ma}$ & July 1998 \\
\hline $\begin{array}{l}\text { No. 249: Impacts of the Indonesian Economic Crisis: Price Changes and } \\
\text { the Poor }\end{array}$ & $\begin{array}{l}\text { hn, Steven Berry, } \\
\text { an }\end{array}$ & 1999 \\
\hline $\begin{array}{l}\text { No. 248: Internal Barriers in the Transition of Enterprises from Central } \\
\text { Plan to Market }\end{array}$ & Charalambos Vlachoutsicos & July 1999 \\
\hline $\begin{array}{l}\text { No. 247: Spillovers from Multinationals in Developing Countries: the } \\
\text { Mechanisms at Work }\end{array}$ & Rich & 999 \\
\hline $\begin{array}{l}\text { No. 246: Dynamism and Inertia on the Russian Labour Market: A } \\
\text { Model of Segmentation }\end{array}$ & $\begin{array}{l}\text { Irena Grosfeld, Claudia Senik- } \\
\text { Leygonie, Thierry Verdier, Stanislav } \\
\text { Kolenikov and Elena Paltseva }\end{array}$ & 999 \\
\hline No. 245: Lesso & John Bol & May 1999 \\
\hline $\begin{array}{l}\text { No. 244: Nominal-Real Tradeoffs and the Effects of Monetary Policy: } \\
\text { the Romanian Experience }\end{array}$ & Christian Popa & Dec. 1998 \\
\hline $\begin{array}{l}\text { No. 243: Privatization, Political Risk and Stock Market Development in } \\
\text { Emerging Economies }\end{array}$ & $\begin{array}{l}\text { Enrico C. Perotti and Pieter van } \\
\text { Oijen }\end{array}$ & Mar. 1999 \\
\hline
\end{tabular}


Davidson Institute Working Papers are available at: www.wdi.bus.umich.edu

\begin{tabular}{|c|c|c|}
\hline No. 242: Investment Financing in Russian Financial-Industrial Groups & $\begin{array}{l}\text { Enrico C. Perotti and Stanislav } \\
\text { Gelfer }\end{array}$ & Oct. 1998 \\
\hline $\begin{array}{l}\text { No. 241: Can governments maintain hard budget constraints? Bank } \\
\text { lending and financial isolation in Romania }\end{array}$ & $\begin{array}{l}\text { Octavian Carare, Constantijn } \\
\text { Claessens, Enrico C. Perotti }\end{array}$ & Jan. 1999 \\
\hline $\begin{array}{l}\text { No. 240: Democratic Institutions and Economic Reform: the Polish } \\
\text { Case }\end{array}$ & $\begin{array}{l}\text { John E. Jackson, Jacek Klich, and } \\
\text { Krystyna Poznanska }\end{array}$ & Apr. 1998 \\
\hline No. 239: A Longitudinal Study of IJV Performance in Eastern Europe & $\begin{array}{l}\text { Keith D. Brouthers and Gary } \\
\text { Bamossy }\end{array}$ & June 1999 \\
\hline $\begin{array}{l}\text { No. 238: Published in: Journal of Business Venturing, "Firm Creation } \\
\text { and Economic Transitions" } 14(5,6) \text { Sep/Nov 1999, pp. 427-450. }\end{array}$ & $\begin{array}{l}\text { John E. Jackson, Jacek Klich, } \\
\text { Krystyna Poznanska }\end{array}$ & July 1998 \\
\hline No. 237: Analysis of Entrepreneurial Attitudes in Poland & $\begin{array}{l}\text { John E. Jackson and Aleksander } \\
\text { S. Marcinkowski }\end{array}$ & Mar. 1997 \\
\hline $\begin{array}{l}\text { No. 236: Investment and Finance in De Novo Private Firms: Empirical } \\
\text { Results from the Czech Republic, Hungary, and Poland }\end{array}$ & $\begin{array}{l}\text { Andrzej Bratkowski, Irena } \\
\text { Grosfeld, Jacek Rostowski }\end{array}$ & Apr. 1999 \\
\hline $\begin{array}{l}\text { No. 235: Does a Soft Macroeconomic Environment Induce } \\
\text { Restructuring on the Microeconomic Level during the Transition } \\
\text { Period? Evidence from Investment Behavior of Czech Enterprises }\end{array}$ & Lubomír Lízal & June 1999 \\
\hline $\begin{array}{l}\text { No. 234: Banking Reform in China: Gradually Strengthening Pillar or } \\
\text { Fragile Reed? }\end{array}$ & John Bonin & June 1999 \\
\hline $\begin{array}{l}\text { No. 233: Theories of Soft Budget Constraints and the Analysis of } \\
\text { Banking Crises }\end{array}$ & Janet Mitchell & Mar. 1999 \\
\hline $\begin{array}{l}\text { No. 232: Unemployment Risk, Precautionary Savings, and } \\
\text { Moonlighting in Russia }\end{array}$ & $\begin{array}{l}\text { Alessandra Guariglia and Byung- } \\
\text { Yeon Kim }\end{array}$ & June 1999 \\
\hline $\begin{array}{l}\text { No. 231: Investing in Turbulent Times: The Investment Behavior of } \\
\text { Polish Firms in the Transition }\end{array}$ & $\begin{array}{l}\text { Josef C. Brada, Arthur E. King, } \\
\text { and Chia-Ying Ma }\end{array}$ & Apr. 1999 \\
\hline No. 230: The End of Moderate Inflation in Three Transition Economies? & Josef C. Brada and Ali M. Kutan & Apr. 1999 \\
\hline $\begin{array}{l}\text { No. 229: Back to the Future: The Growth Prospects of Transition } \\
\text { Economies Reconsidered }\end{array}$ & Nauro F. Campos & Apr. 1999 \\
\hline No. 228: The Enterprise Isolation Program in Russia & n Djankov & Apr. 1999 \\
\hline $\begin{array}{l}\text { No. 227: Published in: Journal of Comparative Economics, "Ownership } \\
\text { Concentration and Corporate Performance in the Czech Republic" } \\
27(3) \text {, Sept. 1999, pp. } 498-513 \text {. }\end{array}$ & $\begin{array}{l}\text { Stijn Claessens and Simeon } \\
\text { Djankov }\end{array}$ & Apr. 1999 \\
\hline $\begin{array}{l}\text { No. 226: Published in Journal of Population Economics, "Poland on the } \\
\text { Dole: The Effect of Reducing the Unemployment Benefit Entitlement } \\
\text { Period during Transition" 13: 35-44, } 2000 \text {. }\end{array}$ & Patrick A. Puhani & Mar. 1999 \\
\hline No. 225: Transition at Whirlpool-Tatramat: Case Studies & $\begin{array}{l}\text { Hans Brechbuhl and Sonia } \\
\text { Ferencikova }\end{array}$ & Mar. 1999 \\
\hline $\begin{array}{l}\text { No. 224: Measuring Progress in Transition and Towards EU Accession: } \\
\text { A Comparison of Manufacturing Firms in Poland, Romania, and Spain }\end{array}$ & $\begin{array}{l}\text { Wendy Carlin, Saul Estrin, and } \\
\text { Mark Schaffer }\end{array}$ & Mar. 1999 \\
\hline $\begin{array}{l}\text { No. 223: Product Market Competition in Transition Economies: } \\
\text { Increasing Varieties and Consumer Loyalty }\end{array}$ & Mitsutoshi M. Adachi & Mar. 1999 \\
\hline $\begin{array}{l}\text { No. 222: Opaque Markets and Rapid Growth: the Superiority of Bank- } \\
\text { Centered Financial Systems for Developing Nations }\end{array}$ & Rodney Wallace & July 1999 \\
\hline No. 221: Technology Spillovers through Foreign Direct Investment & Yuko Kinoshita & Jan. 1999 \\
\hline $\begin{array}{l}\text { No. 220: Managerial, Expertise and Team Centered Forms of } \\
\text { Organizing: A Cross-Cultural Exploration of Independence in } \\
\text { Engineering Work }\end{array}$ & Leslie Perlow & Jan. 1999 \\
\hline $\begin{array}{l}\text { No. 219: Household Structure and Labor Demand in Agriculture: } \\
\text { Testing for Separability in Rural China }\end{array}$ & $\begin{array}{l}\text { Audra J. Bowlus and Terry } \\
\text { Sicular }\end{array}$ & Jan. 1999 \\
\hline $\begin{array}{l}\text { No. 218: Competing Strategies of FDI and Technology Transfer to } \\
\text { China: American and Japanese Firms }\end{array}$ & $\begin{array}{l}\text { W. Mark Fruin and Penelope } \\
\text { Prime }\end{array}$ & Jan. 1999 \\
\hline $\begin{array}{l}\text { No. } 217 \text { Published in: Journal of Comparative Economics, "Returns to } \\
\text { Mobility in the Transition to a Market Economy" } 27(1) \text {, Mar } 1999 .\end{array}$ & $\begin{array}{l}\text { Tito Boeri and Christopher J. } \\
\text { Flinn }\end{array}$ & Jan. 1999 \\
\hline $\begin{array}{l}\text { No. } 216 \text { Published in: Journal of Comparative Economics, "Labor } \\
\text { Market Policies and Unemployment in the Czech Republic." 27(1), Mar } \\
\text { 1999, pp. 33-60. }\end{array}$ & Katherine Terrell and Vit Sorm & Nov. 1998 \\
\hline
\end{tabular}


No. 215 Published in: Journal of Comparative Economics, "Active Labor Market Policies in Poland: Human Capital Enhancement, Stigmatization or Benefit Churning?" 27(1), Mar 1999, pp. 61-. No. 214 Published in: Journal of Comparative Economics, "Does the Slovenian Public Work Program Increase Participants' Chances to Find a Job?" 27(1), Mar 1999, pp. 113- .

No. 213 Published in: Journal of Comparative Economics, "Effects of Active Labor Market Programs on the Transition Rate from Unemployment into Regular Jobs in the Slovak Republic." 27(1), Mar 1999, pp. 90- .

No. 212: The Marketing System in Bulgarian Livestock Production The Present State and Evolutionary Processes During the Period of Economic Transition

No. 211: Bankruptcy Experience in Hungary and the Czech Republic No 210: Values, Optimum Stimulation Levels and Brand Loyalty: New Scales in New Populations

No. 209: Inherited Wealth, Corporate Control and Economic Growth

No. 208: A Cultural Analysis of Homosocial Reproduction and Contesting Claims to Competence in Transitional Firms No. 207: From Survival to Success: The Journey of Corporate Transformation at Haier. Forthcoming in Managing Organizational Change in Transition Economies ed. Daniel Denison.

No. 206: Why Do People Work If They Are Not Paid? An Example from Eastern Europe. Forthcoming in Managing Organizational Change in Transition Economies.

No. 205: Firm Ownership and Work Motivation in Bulgaria and Hungary: An Empirical Study of the Transition in the Mid-1990s. Forthcoming in Managing Organizational Change in Transition Economies ed. Daniel Denison.

No. 204: Human Resource Management in the Restructuring of Chinese Joint Ventures. Forthcoming in Managing Organizational Change in Transition Economies ed. Daniel Denison.

No. 203: Emergent Compensation Strategies in Post-Socialist Poland: Understanding the Cognitive Underpinnings of Management Practices in a Transition Economy. Forthcoming in Managing Organizational Change in Transition Economies ed. Daniel Denison.

No. 202: Corporate Transformation and Organizational Learning: The People's Republic of China. Forthcoming in Managing Organizational Change in Transition Economies ed. Daniel Denison.

No. 201: Foreign Direct Investment as a Factor of Change: The Case of Slovakia. Forthcoming in Managing Organizational Change in Transition Economies ed. Daniel Denison.

No. 200: Radical versus Incremental Change: The Role of Capabilities, Competition, and Leaders. Forthcoming in Managing Organizational Change in Transition Economies ed. Daniel Denison.

No. 199: The Emergence of Market Practices in China's Economic Transition: Price Setting Practices in Shanghai's Industrial Firms. Forthcoming in Managing Organizational Change in Transition Economies ed. Daniel Denison.

No. 198: The Application of Change Management Methods at Business Organizations Operating in Hungary: Challenges in the Business and Cultural Environment and First Practical Experiences. Forthcoming in Managing Organizational Change in Transition Economies ed. Daniel Denison.

\begin{tabular}{|c|c|}
\hline $\begin{array}{l}\text { Jochen Kluve, Hartmut Lehmann, } \\
\text { and Christoph M. Schmidt }\end{array}$ & Dec. 1998 \\
\hline Milan Vodopivec & Dec. 1998 \\
\hline $\begin{array}{l}\text { Martina Lubyova and Jan C. van } \\
\text { Ours }\end{array}$ & Dec. 1998 \\
\hline Yordan Staykov, Team Leader & Oct. 1998 \\
\hline Janet Mitchell & Oct. 1998 \\
\hline $\begin{array}{l}\text { Steven M. Burgess and Mari } \\
\text { Harris }\end{array}$ & Sept. 1998 \\
\hline $\begin{array}{l}\text { Randall K. Morck, David A. } \\
\text { Stangeland, and Bernard Yeung }\end{array}$ & Sept. 1998 \\
\hline Michael D. Kennedy & July 1998 \\
\hline $\begin{array}{l}\text { Arthur Yeung and Kenneth } \\
\text { DeWoskin }\end{array}$ & July 1998 \\
\hline Irina L. Zinovieva & May 1998 \\
\hline $\begin{array}{l}\text { Robert A. Roe, Irina L. } \\
\text { Zinovieva, Elizabeth Dienes, and } \\
\text { Laurens A. ten Horn }\end{array}$ & May 1998 \\
\hline Nandani Lynton & Apr. 1998 \\
\hline Marc Weinstein & Mar. 1998 \\
\hline $\begin{array}{l}\text { Meinolf Dierkes and Zhang } \\
\text { Xinhua }\end{array}$ & Mar. 1998 \\
\hline Sonia Ferencikova & Feb. 1998 \\
\hline Karen L. Newman & Feb. 1998 \\
\hline Douglas Guthrie & Feb. 1998 \\
\hline Dr. János Fehér & Jan. 1998 \\
\hline
\end{tabular}




\begin{tabular}{|c|c|c|}
\hline $\begin{array}{l}\text { No. 197: Organizational Changes in Russian Industrial Enterprises: } \\
\text { Mutation of Decision-Making Structures and Transformations of } \\
\text { Ownership. Forthcoming in Managing Organizational Change in } \\
\text { Transition Economies ed. Daniel Denison. }\end{array}$ & Igor B. Gurkov & Jan. 1998 \\
\hline $\begin{array}{l}\text { No. 196: Understanding and Managing Challenges to the Romanian } \\
\text { Companies during Transition. Forthcoming in Managing Organizational } \\
\text { Change in Transition Economies ed. Daniel Denison. }\end{array}$ & $\begin{array}{l}\text { Dan Candea and Rodica M. } \\
\text { Candea }\end{array}$ & Jan. 1998 \\
\hline $\begin{array}{l}\text { No. 195: Insider Lending and Economic Transition: The Structure, } \\
\text { Function, and Performance Impact of Finance Companies in Chinese } \\
\text { Business Groups. Forthcoming in Managing Organizational Change in } \\
\text { Transition Economies ed. Daniel Denison. }\end{array}$ & Lisa A. Keister & Dec. 1997 \\
\hline $\begin{array}{l}\text { No. 194: Japanese Investment in Transitional Economies: } \\
\text { Characteristics and Performance. Forthcoming in Managing } \\
\text { Organizational Change in Transition Economies ed. Daniel Denison. }\end{array}$ & $\begin{array}{l}\text { Paul W. Beamish and Andrew } \\
\text { Delios }\end{array}$ & Nov. 1997 \\
\hline $\begin{array}{l}\text { No. 193: Building Successful Companies in Transition Economies. } \\
\text { Forthcoming in Managing Organizational Change in Transition } \\
\text { Economies ed. Daniel Denison. }\end{array}$ & Dr. Ivan Perlaki & Jan. 1998 \\
\hline $\begin{array}{l}\text { No. 192: Russian Communitariansim: An Invisible Fist in the } \\
\text { Transformation Process of Russia. Forthcoming in Managing } \\
\text { Organizational Change in Transition Economies ed. Daniel Denison. }\end{array}$ & Charalambos Vlachoutsicos & July 1998 \\
\hline No. 191: Teaching the Dinosaurs to Dance & Michal Cakrt & Sept. 1997 \\
\hline $\begin{array}{l}\text { No. 190: Strategic Restructuring: Making Capitalism in Post- } \\
\text { Communist Eastern Europe. Forthcoming in Managing Organizational } \\
\text { Change in Transition Economies ed. Daniel Denison. }\end{array}$ & Lawrence P. King & Sept. 1997 \\
\hline $\begin{array}{l}\text { No. 189: Published in: Regional Science and Urban Economics, } \\
\text { "Russia's Internal Border." 29(5), Sept. } 1999 .\end{array}$ & $\begin{array}{l}\text { Daniel Berkowitz and David N. } \\
\text { DeJong }\end{array}$ & July 1998 \\
\hline No. 187: Corporate Structure and Performance in Hungary & László Halpern and Gábor Kórsöi & July 1998 \\
\hline No. 186: Performance of Czech Companies by Ownership Structure & $\begin{array}{l}\text { Andrew Weiss and Georgiy } \\
\text { Nikitin }\end{array}$ & June 1998 \\
\hline $\begin{array}{l}\text { No. 185: Firm Performance in Bulgaria and Estonia: The effects of } \\
\text { competitive pressure, financial pressure and disorganisation }\end{array}$ & Jozef Konings & July 1998 \\
\hline $\begin{array}{l}\text { No. 184: Investment and Wages during the Transition: Evidence from } \\
\text { Slovene Firms }\end{array}$ & Janez Prasnikar and Jan Svejnar & July 1998 \\
\hline $\begin{array}{l}\text { No. 183: Investment Portfolio under Soft Budget: Implications for } \\
\text { Growth, Volatility and Savings }\end{array}$ & Chongen Bai and Yijiang Wang & July 1998 \\
\hline No. 181: Delegation and Delay in Bank Privatization & $\begin{array}{l}\text { Loránd Ambrus-Lakatos and } \\
\text { Ulrich Hege }\end{array}$ & July 1998 \\
\hline No. 180: Financing Mechanisms and R\&D Investment & $\begin{array}{l}\text { Haizhou Huang and Chenggang } \\
\mathrm{Xu}\end{array}$ & July 1998 \\
\hline $\begin{array}{l}\text { No. 179: Organizational Culture and Effectiveness: The Case of Foreign } \\
\text { Firms in Russia }\end{array}$ & $\begin{array}{l}\text { Carl F. Fey and Daniel R. } \\
\text { Denison }\end{array}$ & Jan. 1999 \\
\hline No. 178: Output and Unemployment Dynamics in Transition & $\begin{array}{l}\text { Vivek H. Dehejia and Douglas W. } \\
\text { Dwyer }\end{array}$ & Jan. 1998 \\
\hline $\begin{array}{l}\text { No. 177: Published in: Economics of Transition, "Bureaucracies in the } \\
\text { Russian Voucher Privatization." 8(1), 2000, pp. 37-57. }\end{array}$ & Guido Friebel & June 1998 \\
\hline No. 176: Chronic Moderate Inflation in Transition: The Tale of Hungary & János Vincze & June 1998 \\
\hline No. 175: Privatisation and Market Structure in a Transition Economy & John Bennett and James Maw & June 1998 \\
\hline $\begin{array}{l}\text { No. 174: Ownership and Managerial Competition: Employee, Customer, } \\
\text { or Outside Ownership }\end{array}$ & $\begin{array}{l}\text { Patrick Bolton and Chenggang } \\
\mathrm{Xu}\end{array}$ & June 1998 \\
\hline $\begin{array}{l}\text { No. 173: Intragovernment Procurement of Local Public Good: A } \\
\text { Theory of Decentralization in Nondemocratic Government }\end{array}$ & $\begin{array}{l}\text { Chong-en Bai, Yu Pan and } \\
\text { Yijiang Wang }\end{array}$ & June 1998 \\
\hline No. 172: Political Instability and Growth in Proprietary Economies & $\begin{array}{l}\text { Jody Overland and Michael } \\
\text { Spagat }\end{array}$ & Aug. 1998 \\
\hline $\begin{array}{l}\text { No. 171: Published in Post-Communist Economies, "Framework Issues } \\
\text { in the Privatization Strategies of the Czech Republic, Hungary, and } \\
\text { Poland" 11(1) Mar. 1999. }\end{array}$ & Morris Bornstein & 1998 \\
\hline
\end{tabular}


Davidson Institute Working Papers are available at: www.wdi.bus.umich.edu

\begin{tabular}{|c|c|c|}
\hline $\begin{array}{l}\text { No. 170: Published in: European Journal of Political Economy } \\
\text { "Privatization, Ownership Structure and Transparency: How to Measure } \\
\text { a Real Involvement of the State" 15(4), Nov. 1999, pp. 605-18. }\end{array}$ & Frantisek Turnovec & May 1998 \\
\hline $\begin{array}{l}\text { No. } 169 \text { Published in: American Economic Review, "Unemployment and } \\
\text { the Social Safety Net during Transitions to a Market Economy: } \\
\text { Evidence from Czech and Slovak Men" 88(5), Dec 1998, pp. 1117-1142 }\end{array}$ & $\begin{array}{l}\text { John C. Ham, Jan Svejnar, and } \\
\text { Katherine Terrell }\end{array}$ & Dec. 1998 \\
\hline $\begin{array}{l}\text { No. 167: Voucher Privatization with Investment Funds: An Institutional } \\
\text { Analysis }\end{array}$ & David Ellerman & Mar. 1998 \\
\hline $\begin{array}{l}\text { No. 166: Published in: Marketing Issues in Transitional Economies, } \\
\text { "Value Priorities and Consumer Behavior in a Transitional Economy: } \\
\text { The Case of South Africa" ed. Rajeev Batra. }\end{array}$ & $\begin{array}{l}\text { Steven M. Burgess and Jan- } \\
\text { Benedict E.M. Steenkamp }\end{array}$ & Aug. 1998 \\
\hline $\begin{array}{l}\text { No. 164: Finance and Investment in Transition: Czech Enterprises, } \\
\text { 1993-1994 }\end{array}$ & $\begin{array}{l}\text { Ronald Anderson and Chantal } \\
\text { Kegels }\end{array}$ & Sept. 1997 \\
\hline $\begin{array}{l}\text { No. 163: European Union Trade and Investment Flows U-Shaping } \\
\text { Industrial Output in Central and Eastern Europe: Theory and Evidence }\end{array}$ & $\begin{array}{l}\text { Alexander Repkine and Patrick P. } \\
\text { Walsh }\end{array}$ & Apr. 1998 \\
\hline $\begin{array}{l}\text { No. 162: Skill Acquisition and Private Firm Creation in Transition } \\
\text { Economies }\end{array}$ & Zuzana Brixiova and Wenli Li & Oct. 1999 \\
\hline No. 161: Corruption in Transition & Susanto Basu and David D. Li & May 1998 \\
\hline $\begin{array}{l}\text { No. 160a: Tenures that Shook the World: Worker Turnover in Russia, } \\
\text { Poland and Britain }\end{array}$ & $\begin{array}{l}\text { Hartmut Lehmann and Jonathan } \\
\text { Wadsworth }\end{array}$ & Nov. 1999 \\
\hline $\begin{array}{l}\text { No. 160: Tenures that Shook the World: Worker Turnover in the } \\
\text { Russian Federation and Poland }\end{array}$ & $\begin{array}{l}\text { Hartmut Lehmann and Jonathan } \\
\text { Wadsworth }\end{array}$ & June 1998 \\
\hline No. 159: Does Market Structure Matter? New Evidence from Russia & $\begin{array}{l}\text { Annette N. Brown and J. David } \\
\text { Brown }\end{array}$ & June 1998 \\
\hline $\begin{array}{l}\text { l Adjustment and Regional Long Term } \\
\text { Poland }\end{array}$ & $\begin{array}{l}\text { Hartmut Lehmann and Patrick P. } \\
\text { Walsh }\end{array}$ & 1997 \\
\hline $\begin{array}{l}\text { No. 157: Baby Boom or Bust? Changing Fertility in Post-Communist } \\
\text { Czech Republic and Slovakia }\end{array}$ & Robert S. Chase & Apr. 1998 \\
\hline $\begin{array}{l}\text { No. } 156 \text { Published in: Leadership and Organization Development } \\
\text { Journal, "Leading Radical Change in Transition Economies." Vol. 19, } \\
\text { No. 6, 1998, pp. 309-324. }\end{array}$ & Karen L. Newman & June 1998 \\
\hline $\begin{array}{l}\text { No. } 155 \text { Published in: Oxford Review of Economic Policy, "From } \\
\text { Theory into Practice? Restructuring and Dynamism in Transition } \\
\text { Economies." Vol. 13, No. 2, Summer 1997, pp. 77-105. }\end{array}$ & $\begin{array}{l}\text { Wendy Carlin and Michael } \\
\text { Landesmann }\end{array}$ & June 1997 \\
\hline $\begin{array}{l}\text { No. 154: The Model and the Reality: Assessment of Vietnamese SOE } \\
\text { Reform-Implementation at the Firm Level }\end{array}$ & $\begin{array}{l}\text { Edmund Malesky, Vu Thanh } \\
\text { Hung, Vu Thi Dieu Anh, and } \\
\text { Nancy K. Napier }\end{array}$ & July 1998 \\
\hline $\begin{array}{l}\text { No. } 153 \text { Published in: Journal of Comparative Economics, "Causes of } \\
\text { the Soft Budget Constraint: Evidence on Three Explanations." Vol. 26, } \\
\text { No. 1, Mar. 1998, pp. 104-116. }\end{array}$ & David D. Li and Minsong Liang & Mar. 1998 \\
\hline $\begin{array}{l}\text { No. } 152 \text { Published in: Comparative Economic Studies, "Enterprise } \\
\text { Restructuring in Russia's Transition Economy: Formal and Informal } \\
\text { Mechanisms." Vol. 40, No. 2, Summer 1998, pp. 5-52. }\end{array}$ & Susan J. Linz and Gary Krueger & Apr. 1998 \\
\hline $\begin{array}{l}\text { No. 151: Labor Productivity in Transition: A Regional Analysis of } \\
\text { Russian Industry }\end{array}$ & Susan J. Linz & May 1998 \\
\hline $\begin{array}{l}\text { No. 150: Tax Avoidance and the Allocation of Credit. Forthcoming in } \\
\text { Financial Systems in Transition: The Design of Financial Systems in } \\
\text { Central Europe eds. Anna Meyendorff and Anjan Thakor. }\end{array}$ & Anna Meyendorff & June 1998 \\
\hline $\begin{array}{l}\text { No. 149: Commitment, Versatility and Balance: Determinants of Work } \\
\text { Time Standards and Norms in a Multi-Country Study of Software } \\
\text { Engineers }\end{array}$ & Leslie Perlow and Ron Fortgang & Apr. 1998 \\
\hline $\begin{array}{l}\text { No. 148: Changes in Poland's Transfer Payments in the 1990s: the Fate } \\
\text { of Pensioners }\end{array}$ & Bozena Leven & June 1998 \\
\hline $\begin{array}{l}\text { No. 147: Environmental Protection and Economic Development: The } \\
\text { Case of the Huaihe River Basin Cleanup Plan }\end{array}$ & $\begin{array}{l}\text { Robert Letovsky, Reze Ramazani, } \\
\text { and Debra Murphy }\end{array}$ & June 1998 \\
\hline
\end{tabular}


No. 146: Chief Executive Compensation During Early Transition: Further Evidence from Bulgaria

No. 145 Published in: Economics of Transition, "Women's

Unemployment During the Transition: Evidence from Czech and Slovak

Micro Data," Vol. 7, No. 1, May 1999, pp. 47-78.

No. 144: Investment and Wages in Slovenia

No. 143 Published in: Review of Financial Studies, "Optimal

Bankruptcy Laws Across Different Economic Systems,” 12(2), 47-77,

Summer 19993.

No. 142: Industrial Policy and Poverty in Transition Economies: Two

Steps Forward or One Step Back?

No. 141 Collective Ownership and Privatization of China's Village

Enterprises

No. 140 A Comparative Look at Labor Mobility in the Czech Republic:

Where have all the Workers Gone?

No. 139 The Failure of the Government-Led Program of Corporate

Reorganization in Romania

No. 138 Ownership and Employment in Russian Industry: 1992-1995

No. 137 Published in: Journal of Political Economy, "Reform Without

Losers: An Interpretation of China's Dual-Track Approach to

Transition," Feb. 2000; Vol. 108, Iss.1; pg. 120

No. 136 Published in: European Economic Review, "The Political

Economy of Mass Privatization and the Risk of Expropriation," 44(2),

Feb. 2000, pgs. 393-421

No. 135: Radical Organizational Change: The Role of Starting

Conditions, Competition, and Leaders

No. 134: To Restructure or Not to Restructure: Informal Activities and

Enterprise Behavior in Transition

No. 133: Management 101: Behavior of Firms in Transition Economies

No. 132 Published in: Quarterly Journal of Economics, "Interfirm

Relationships and Informal Credit in Vietnam," 114(4), Nov. 1999, pgs.

$1285-1320$

No. 131 Published in: Comparative Economic Studies, "Will

Restructuring Hungarian Companies Innovate? An Investigation Based

on Joseph Berliner's Analysis of Innovation in Soviet Industry." Vol.

40, No. 2, Summer 1998, pp. 53-74.

No. 130: Published in The American Economic Review, "Changing

Incentives of the Chinese Bureaucracy." May, 1998.

No. 129: Restructuring Investment in Transition: A Model of the

Enterprise Decision

No. 128 Published in: Comparative Economic Studies, "Job Rights in

Russian Firms: Endangered or Extinct Institutions?" Vol. 40, No. 4,

Winter 1998, pp. 1-32.

No. 127: Accounting for Growth in Post-Soviet Russia

No. 126 Published in: Economics of Transition, "From Federalism, Chinese Style, to Privatization Chinese Style," 7(1), 1999, pgs. 103-31

No. 125: Market Discipline in Conglomerate Banks: Is an Internal Allocation of Cost of Capital Necessary as Incentive Device?

Forthcoming in Financial Systems in Transition: The Design of

Financial Systems in Central Europe eds. Anna Meyendorff and Anjan

Thakor.

No. 124: Financial Discipline in the Enterprise Sector in Transition

Countries: How Does China Compare?

No. 123: Considerations of an Emerging Marketplace: Managers'

Perceptions in the Southern African Economic Community
Derek C. Jones, Takao Kato, and Jeffrey Miller

John Ham, Jan Svejnar, and

Katherine Terrell

Janez Prasnikar

May 1998

Elazar Berkovitch and Ronen

Israel

Susan J. Linz

Mar. 1998

Suwen Pan and Albert Park

Apr. 1998

Vit Sorm and Katherine Terrell

Apr. 1999

Simeon Djankov and Kosali

Ilayperuma

Susan J. Linz

Sept. 1997

Lawrence J. Lau, Yingyi Qian,

and Gerard Roland

Klaus M. Schmidt

Mar. 1998

Karen L. Newman

Jan. 1998

Clifford Gaddy and Barry W. Ickes

Josef C. Brada

John McMillan and Christopher

Woodruff

John B. Bonin and Istvan Abel

Mar. 1998

John B. Bonin and Istvan Abel

David D. Li

Jan. 1998

Richard E. Ericson

Jan. 1998

Susan J. Linz

Jan. 1998

Daniel Berkowitz and David N.

Jan. 1998

DeJong

Yuanzheng Cao, Yingyi Qian,

Dec. 1997

and Barry R. Weingast

Arnoud W. A. Boot and Anjolein

Nov. 1997

Schmeits

Shumei Gao and Mark E.

Feb. 1998

Schaffer

Brent Chrite and David Hudson

Feb. 1998 
Davidson Institute Working Papers are available at: www.wdi.bus.umich.edu

\begin{tabular}{|c|c|c|}
\hline No. 122: A Model of the Informal Economy in Transition Economies & $\begin{array}{l}\text { Simon Commander and Andrei } \\
\text { Tolstopiatenko }\end{array}$ & Nov. 1997 \\
\hline $\begin{array}{l}\text { No. 121: Local Labour Market Dynamics in the Czech and Slovak } \\
\text { Republics }\end{array}$ & $\begin{array}{l}\text { Peter Huber and Andreas } \\
\text { Worgotter }\end{array}$ & Nov. 1997 \\
\hline $\begin{array}{l}\text { No. 119: Published in Academy of Management Review, "Organizational } \\
\text { Transformation during Institutional Upheaval," } 25 \text { (3), 2000, p. 602-619 }\end{array}$ & Karen L. Newman & Mar. 1998 \\
\hline No. 118: Industrial Decline and Labor Reallocation in Romania & John S. Earle & Oct. 1997 \\
\hline No. 117: Notes for an Essay on the Soft Budget Constraint & Lorand Ambrus-Lakatos & Jan. 1997 \\
\hline No. 116: Labor Demand During Transition in Hungary & Gabor Korosi & Oct. 1997 \\
\hline No. 115: Enterprise Performance and Managers' Profiles & $\begin{array}{l}\text { Simeon Djankov and Stijn } \\
\text { Claessens }\end{array}$ & Dec. 1997 \\
\hline $\begin{array}{l}\text { No. 114b Employment and Wages in Enterprises under Communism } \\
\text { and in Transition: Evidence From Central Europe and Russia }\end{array}$ & $\begin{array}{l}\text { Swati Basu, Saul Estrin, and Jan } \\
\text { Svejnar }\end{array}$ & Apr. 2000 \\
\hline $\begin{array}{l}\text { No. 114: Employment and Wage Behavior of Enterprises in Transitional } \\
\text { Economies }\end{array}$ & $\begin{array}{l}\text { Swati Basu, Saul Estrin, and Jan } \\
\text { Svejnar }\end{array}$ & Oct. 1997 \\
\hline $\begin{array}{l}\text { No. 113: Preliminary Evidence on Active Labor Programs' Impact in } \\
\text { Hungary and Poland }\end{array}$ & Christopher J. O’Leary & Oct. 1997 \\
\hline $\begin{array}{l}\text { No. 111: Unemployment Benefits and Incentives in Hungary: New } \\
\text { Evidence }\end{array}$ & Joachim Wolff & Oct. 1997 \\
\hline $\begin{array}{l}\text { No. 110: Published in: Empirical Economics, "Long-Term } \\
\text { Unemployment, Unemployment Benefits and Social Assistance: The } \\
\text { Polish Experience" Empirical-Economics; 23(1-2), 1998, pp. 55-85. }\end{array}$ & $\begin{array}{l}\text { Marek Gora and Christoph M. } \\
\text { Schmidt }\end{array}$ & Apr. 1997 \\
\hline $\begin{array}{l}\text { No. } 109 \text { Published in: Industrial and Labor Relations Review, "Markets } \\
\text { for Communist Human Capital: Returns to Education and Experience in } \\
\text { Post-Communist Czech Republic and Slovakia." 51(3), Apr. 1998, pp. } \\
\text { 401-423. }\end{array}$ & t S. Chase & Oct. 1997 \\
\hline $\begin{array}{l}\text { No. 107: The Worker-Firm Matching in the Transition: (Why) Are the } \\
\text { Czechs More Successful Than Others? }\end{array}$ & Jan Svejnar, and & 997 \\
\hline $\begin{array}{l}\text { No. } 106 \text { Published in: Journal of Comparative Economics, "Job } \\
\text { Creation, Job Destruction and Growth of Newly Established, Privatized } \\
\text { and State-Owned Enterprises in Transition Economies: Survey Evidence } \\
\text { from Bulgaria, Hungary, and Romania," 26(3), Sept. 1998, pp. 429-445. }\end{array}$ & $\begin{array}{l}\text { Valentijn Bilsen and Jozef } \\
\text { Konings }\end{array}$ & Sept. 1998 \\
\hline $\begin{array}{l}\text { No. 105: Getting Behind the East-West [German] Wage Differential: } \\
\text { Theory and Evidence }\end{array}$ & $\begin{array}{l}\text { Michael Burda and Christoph } \\
\text { Schmidt }\end{array}$ & May 1997 \\
\hline f the "Wage Curve" in Hungary, 1989-95 & Gabor Kertesi and Janos Kollo & Oct. 1997 \\
\hline $\begin{array}{l}\text { No. 103: Published in: Journal of Comparative Economics, "Grime and } \\
\text { Punishment: Job Insecurity and Wage Arrears in the Russian } \\
\text { Federation" 27, 595-617 (1999). }\end{array}$ & $\begin{array}{l}\text { Hartmut Lehmann, Jonathan } \\
\text { Wadsworth, and Alessandro } \\
\text { Acquisti }\end{array}$ & Oct. 1997 \\
\hline No. 102: Social Networks in Transition & $\begin{array}{l}\text { Lorena Barberia, Simon Johnson, } \\
\text { and Daniel Kaufmann }\end{array}$ & Oct. 1997 \\
\hline $\begin{array}{l}\text { No. 101: Depreciation and Russian Corporate Finance: A Pragmatic } \\
\text { Approach to Surviving the Transition }\end{array}$ & Susan J. Linz & Nov. 1997 \\
\hline No. 100: Romanian Financial System Reform & $\begin{array}{l}\text { Anna Meyendorff and Anjan V. } \\
\text { Thakor }\end{array}$ & Nov. 1997 \\
\hline $\begin{array}{l}\text { No. 99: Proceedings of the Conference on Strategic Alliances in } \\
\text { Transitional Economies, held May 20, } 1997 \text { at the Davidson Institute }\end{array}$ & Edited by Cynthia Koch & May 1997 \\
\hline No. 98: Institutions, Strain and the Underground Economy & Daniel Daianu and Lucian Albu & Nov. 1997 \\
\hline No. 97: Structure and Strain in Explaining Inter-Enterprise Arrears & Daniel Daianu & Nov. 1997 \\
\hline $\begin{array}{l}\text { No. 96: Resource Misallocation and Strain: Explaining Shocks in Post- } \\
\text { Command Economies }\end{array}$ & Daniel Daianu & Nov. 1997 \\
\hline $\begin{array}{l}\text { No. 95: Published in: Finance-a-Uver, “Czech Money Market: Emerging } \\
\text { Links Among Interest Rates.” 48(2) } 1998 \text { pp. 99-109. }\end{array}$ & $\begin{array}{l}\text { Jan Hanousek and Evzen } \\
\text { Kocenda }\end{array}$ & Nov. 1997 \\
\hline $\begin{array}{l}\text { No. 94: Pre-Reform Industry and the } \\
\text { State Monopsony in China }\end{array}$ & $\begin{array}{l}\text { Xiao-Yuan Dong and Louis } \\
\text { Putterman }\end{array}$ & Oct. 1997 \\
\hline
\end{tabular}


Davidson Institute Working Papers are available at: www.wdi.bus.umich.edu

\begin{tabular}{|c|c|c|}
\hline $\begin{array}{l}\text { No. 93: China's State-Owned Enterprises } \\
\text { In the First Reform Decade: } \\
\text { An Analysis of a Declining Monopsony }\end{array}$ & $\begin{array}{l}\text { Xiao-Yuan Dong and Louis } \\
\text { Putterman }\end{array}$ & Oct. 1997 \\
\hline No. 92: Expatriate Management in the Czech Republic & Richard B. Peterson & Sept. 1997 \\
\hline No. 91: China and the Idea of Economic Reform & Thomas G. Rawski & Apr. 1997 \\
\hline $\begin{array}{l}\text { No. } 90 \text { Published in: China Economic Review, "China’s State Enterprise } \\
\text { Reform: An Overseas Perspective." Vol. 8, Spring 1997, pp. 89-98. }\end{array}$ & Thomas G. Rawski & July 1997 \\
\hline $\begin{array}{l}\text { No. 89: The Economic Determinants of Internal Migration Flows in } \\
\text { Russia During Transition }\end{array}$ & Annette N. Brown & July 1997 \\
\hline $\begin{array}{l}\text { No. 88: Gender Wage Gaps in China's Labor Market: Size, Structure, } \\
\text { Trends }\end{array}$ & $\begin{array}{l}\text { Margaret Maurer-Fazio, Thomas } \\
\text { G. Rawski, and Wei Zhang }\end{array}$ & July 1997 \\
\hline No. 87: Privatisation in Central and Eastern Europe & Saul Estrin & June 1997 \\
\hline $\begin{array}{l}\text { No. 86: Published in : Economics of Transition, "The Effect of } \\
\text { Privatization on Wealth Distribution in Russia." v. 7, no. 2, 1999, pp. } \\
449-65\end{array}$ & Michael Alexeev & Feb. 1998 \\
\hline $\begin{array}{l}\text { No. 85: Was Privatization in Eastern Germany a Special Case? Some } \\
\text { Lessons from the Treuhand }\end{array}$ & Uwe Siegmund & Sept. 1997 \\
\hline No. 84: Start-ups and Transition & $\begin{array}{l}\text { Daniel M. Berkowitz and David J. } \\
\text { Cooper }\end{array}$ & Sept. 1997 \\
\hline $\begin{array}{l}\text { No. 83: Which Enterprises (Believe They) Have Soft Budgets after } \\
\text { Mass Privatization? Evidence from Mongolia }\end{array}$ & $\begin{array}{l}\text { James Anderson, Georges } \\
\text { Korsun, and Peter Murrell }\end{array}$ & Oct. 1997 \\
\hline $\begin{array}{l}\text { No. 82: Published in: European Economic Review, "Unemployment } \\
\text { Dynamics and the Restructuring of the Slovak Unemployment Benefit } \\
\text { System." Apr., } 1997 .\end{array}$ & $\begin{array}{l}\text { Martina Lubyova and Jan C. van } \\
\text { Ours }\end{array}$ & June 1997 \\
\hline No. 81: Determinants of Unemployment Duration in Russia & Mark C. Foley & Aug. 1997 \\
\hline No. 80: The Many Faces of Information Disclosure & $\begin{array}{l}\text { Arnoud W.A. Boot and Anjan V. } \\
\text { Thakor }\end{array}$ & Oct. 1997 \\
\hline $\begin{array}{l}\text { No. 79: Published in: Journal of Finance, "Foreign Speculators and } \\
\text { Emerging Equity Markets."v.22, iss. 2, 2000, pp. 565-613 }\end{array}$ & $\begin{array}{l}\text { Geert Bekaert and Campbell R. } \\
\text { Harvey }\end{array}$ & Aug. 1997 \\
\hline $\begin{array}{l}\text { No. 78: The Relationship Between Economic Factors and Equity } \\
\text { Markets in Central Europe }\end{array}$ & $\begin{array}{l}\text { Jan Hanousek and Randall K. } \\
\text { Filer }\end{array}$ & June 1997 \\
\hline $\begin{array}{l}\text { No. } 77 \text { Published in: Economics of Transition, "A Gini Decomposition } \\
\text { Analysis of Inequality in the Czech and Slovak Republics During the } \\
\text { Transition," Vol. 6, No.1, May 1998, pp. 23-46. }\end{array}$ & $\begin{array}{l}\text { Thesia I. Garner and Katherine } \\
\text { Terrell }\end{array}$ & May 1998 \\
\hline $\begin{array}{l}\text { No. 76: China's Emerging Market for Property Rights: Theoretical and } \\
\text { Empirical Perspectives }\end{array}$ & $\begin{array}{l}\text { Gary H. Jefferson and Thomas G. } \\
\text { Rawski }\end{array}$ & June 1997 \\
\hline $\begin{array}{l}\text { No. 75b: Test of Permanent Income Hypothesis on Czech Voucher } \\
\text { Privatization }\end{array}$ & Jan Hanousek and Zdenek Tima & Oct. 1997 \\
\hline $\begin{array}{l}\text { No. 74: Determinants of Performance of Manufacturing Firms in Seven } \\
\text { European Transition Economies }\end{array}$ & $\begin{array}{l}\text { Stijn Claessens, Simeon Djankov, } \\
\text { and Gerhard Pohl }\end{array}$ & Feb. 1997 \\
\hline $\begin{array}{l}\text { No. } 73 \text { Published in: Economics of Transition, "The Restructuring of } \\
\text { Large Firms in Slovak Republic." Vol. 6, No. 1, May 1998, pp. 67-85 }\end{array}$ & $\begin{array}{l}\text { Simeon Djankov and Gerhard } \\
\text { Pohl }\end{array}$ & May 1998 \\
\hline $\begin{array}{l}\text { No. 72: Law, Relationships, and Private Enforcement: Transactional } \\
\text { Strategies of Russian Enterprises }\end{array}$ & $\begin{array}{l}\text { Kathryn Hendley, Peter Murrell, } \\
\text { and Randi Ryterman }\end{array}$ & Nov. 1998 \\
\hline $\begin{array}{l}\text { No. 71: Giving Credit Where Credit Is Due: The Changing Role of } \\
\text { Rural Financial Institutions in China }\end{array}$ & $\begin{array}{l}\text { Albert Park, Loren Brandt, and } \\
\text { John Giles }\end{array}$ & Mar. 1997 \\
\hline $\begin{array}{l}\text { No. 70: Privatization Versus Competition: Changing Enterprise } \\
\text { Behavior in Russia }\end{array}$ & John S. Earle and Saul Estrin & $\begin{array}{l}\text { Spring } \\
1997\end{array}$ \\
\hline $\begin{array}{l}\text { No. 69: Russian Managers under Storm: Explicit Reality and Implicit } \\
\text { Leadership Theories (A Pilot Exploration) }\end{array}$ & Igor Gurkov & Oct. 1998 \\
\hline $\begin{array}{l}\text { No. 68: The Political Economy of Central-Local Relations in China: } \\
\text { Inflation and Investment Controls During the Reform Era }\end{array}$ & Yasheng Huang & $\begin{array}{l}\text { Spring } \\
1997 \\
\end{array}$ \\
\hline $\begin{array}{l}\text { No. 67: Between Two Coordination Failures: Automotive Industrial } \\
\text { Policy in China with a Comparison to Korea }\end{array}$ & Yasheng Huang & $\begin{array}{l}\text { Spring } \\
1997\end{array}$ \\
\hline
\end{tabular}




\begin{tabular}{|c|c|c|}
\hline $\begin{array}{l}\text { No. } 66 \text { Published in: Post-Soviet Geography and Economics, "Red } \\
\text { Executives in Russia's Transition Economy." Vol. 27, No. 10, Nov. } \\
\text { 1996, pp. 633-651. }\end{array}$ & Susan J. Linz & Jan. 1997 \\
\hline $\begin{array}{l}\text { No. } 65 \text { Published in: Industrial and Corporate Change, "On the } \\
\text { Sequencing of Privatization in Transition Economies." Vol. 7, No. 1, } \\
1998 .\end{array}$ & $\begin{array}{l}\text { Gautam Ahuja and Sumit K. } \\
\text { Majumdar }\end{array}$ & Apr. 1997 \\
\hline $\begin{array}{l}\text { No. 64: Published in: Journal of Law and Economics, "Foreign } \\
\text { Ownership and Profitability: Property Rights, Control and the } \\
\text { Performance of Firms in Indian Industry" 42(1), Apr. 1999, pp. 209-38. }\end{array}$ & $\begin{array}{l}\text { Pradeep K. Chhibber and Sumit } \\
\text { K. Majumdar }\end{array}$ & Apr. 1997 \\
\hline No. 63: How Taxing Is Corruption on International Investors? & Shang-Jin Wei & Feb. 1997 \\
\hline $\begin{array}{l}\text { No. 62: What Can We Learn from the Experience of Transitional } \\
\text { Economies with Labour Market Policies? }\end{array}$ & Tito Boeri & 1997 \\
\hline $\begin{array}{l}\text { No. 61: Published in: Accounting Organizations and Society, } \\
\text { "Economic Transition, Strategy and the Evolution of Management } \\
\text { Accounting Practices: The Case of India" 24(5,6), Jul/Aug 1999, pp. } \\
\text { 379-412. }\end{array}$ & $\begin{array}{l}\text { Shannon W. Anderson and } \\
\text { William N. Lanen }\end{array}$ & Apr. 1997 \\
\hline $\begin{array}{l}\text { No. 60a: Enterprise Investment During the Transition: Evidence from } \\
\text { Czech Panel Data }\end{array}$ & Lubomír Lizal and Jan Svejnar & Dec. 1997 \\
\hline $\begin{array}{l}\text { No. 59: Published in: Journal of Law, Economics, and Organization, } \\
\text { "Institutional Environment, Community Government, and Corporate } \\
\text { Governance: Understanding China's Township-Village Enterprises." } \\
\text { 14(1), Apr. 1998, pages 1-23 }\end{array}$ & Jiah & Apr. 1997 \\
\hline No. 58: From the Grabbing Hand to the Helping Hand & Jiahua Che & June 2000 \\
\hline $\begin{array}{l}\text { No. 57: Published in: Brookings Papers on Economic Activity, "The } \\
\text { Unofficial Economy in Transition." 1: } 1998 .\end{array}$ & $\begin{array}{l}\text { Simon Johnson, Daniel } \\
\text { Kaufmann, and Andrei Schleifer }\end{array}$ & June 1997 \\
\hline No. 56: Taxes and Government Incentives: Eastern Europe vs. China & Roger H. Gordon and David D. Li & Apr. 1997 \\
\hline No. 55: Corruption and Reform & Susanto Basu and David Li & June 1996 \\
\hline $\begin{array}{l}\text { No. 54: Decentralization and the Macroeconomic Consequences of } \\
\text { Commitment to State-Owned Firms }\end{array}$ & Loren Brandt and Xiaodong Zhu & June 1997 \\
\hline $\begin{array}{l}\text { No. 53: Published in: The International Journal of Industrial } \\
\text { Organization, "Competitive Shocks and Industrial Structure: The Case } \\
\text { of Polish Manufacturing." Aug., 1999. . }\end{array}$ & $\begin{array}{l}\text { Pankaj Ghemawat and Robert E. } \\
\text { Kennedy }\end{array}$ & May 1997 \\
\hline $\begin{array}{l}\text { No. 52: Published in: The Quarterly Journal of Economics, "Insecure } \\
\text { Property Rights and Government Ownership of Firms." May, } 1998 .\end{array}$ & Jiahua Che and Yingyi Qian & May 1997 \\
\hline No. 51: Incentives, Scale Economies, and Organizational Form & $\begin{array}{l}\text { Eric Maskin, Yingyi } \\
\text { Chenggang Xu }\end{array}$ & May 1997 \\
\hline $\begin{array}{l}\text { No. 50: Published in: Post-Soviet-Affairs, "End of the Tunnel? The } \\
\text { Effects of Financial Stabilization in Russia" Apr.-June 1997, pages 105- } \\
33\end{array}$ & $\begin{array}{l}\text { Barry W. Ickes, Peter Murrell, } \\
\text { and Randi Ryterman }\end{array}$ & Mar. 1997 \\
\hline $\begin{array}{l}\text { No. 49: The Evolution of Bank Credit Quality in Transition: Theory and } \\
\text { Evidence from Romania }\end{array}$ & $\begin{array}{l}\text { Enrico C. Perott } \\
\text { Carare }\end{array}$ & Oct. 1996 \\
\hline $\begin{array}{l}\text { No. 48: Where Do the Leaders Trade? Information Revelation and } \\
\text { Interactions Between the Segments of Czech Capital Markets }\end{array}$ & $\begin{array}{l}\text { Jan Hanousek and Libor } \\
\text { Nemecek }\end{array}$ & May 1997 \\
\hline $\begin{array}{l}\text { No. 47: Firms' Heterogeneity in Transition: Evidence from a Polish } \\
\text { Panel Data Set }\end{array}$ & $\begin{array}{l}\text { Irena Grosfeld and Jean-François } \\
\text { Nivet }\end{array}$ & May 1997 \\
\hline No. 46: Strategic Creditor Passivity, Regulation, and Bank Bailouts & Janet Mitchell & May 1997 \\
\hline $\begin{array}{l}\text { No. 45a: Published in: Journal of Public Economics, "Tax Rights in } \\
\text { Transition Economies: A Tragedy of the Commons." } 76,2000 \text {, pp. 369- } \\
397\end{array}$ & Daniel M. Berkowitz and Wei Li & Sept. 1997 \\
\hline $\begin{array}{l}\text { No. 44a: The Information Content of Stock Markets: Why do Emerging } \\
\text { Markets have Synchronous Stock Price Movements? (forthcoming in } \\
\text { the Journal of Financial Economics). }\end{array}$ & $\begin{array}{l}\text { Randall Morck, Bernard Yeung, } \\
\text { and Wayne Yu }\end{array}$ & Feb. 1999 \\
\hline $\begin{array}{l}\text { No. 43: Agency in Project Screening and Termination Decisions: Why } \\
\text { Is Good Money Thrown After Bad? }\end{array}$ & Chong-en Bai and Yijiang Wang & May 1997 \\
\hline
\end{tabular}


No. 42: Published in: Economics of Transition, "Channels of Redistribution: Inequality and Poverty in the Russian Transition." Vol. 7 (2) 1999.

No. 41: Published in: Economics of Transition, "Labour Market Characteristics and Profitability: Econometric Analysis of Hungarian Exporting Firms, 1986-1995" 6(1), May 1998, pages 145-62 No. 40: Published in: the Harvard Law Review, "The Tragedy of the Anticommons: Property in the Transition from Marx to Markets." Jan. 1998.

No. 39: Privatization and Managerial Efficiency

No. 38 Published in: The Quarterly Journal of Economics,

"Disorganization." Vol. 112, No. 4, Nov. 1997, pp. 1091-1126.

No. 37: Published in: Economics of Transition, "Transition and the Output Fall." 7(1), 1999, pages 1-28.

No. 36: Restructuring an Industry During Transition: A Two-Period Model

No. 34: The East-West Joint Venture: BC Torsion Case Study

No. 33 Published in: Journal of Comparative Economics, "Quantifying Price Liberalization in Russia." Vol. 26, No. 4, Dec. 1998, pp. 735-737.

No. 32: What Can North Korea Learn from China's Market Reforms?

No. 31: Published in: China-Economic-Review, "Towards a Model of China as a Partially Reformed Developing Economy Under a Semifederalist Government." 9(1), Spring 1998, pages 1-23.

No. 30: Convergence in Output in Transition Economies: Central and Eastern Europe, 1970-1995

No. 29: Published in: Economics of Transition, "Altered Band and Exchange Volatility." Volume 6, no. 1, 1998, 173-181.

No. 28: Published in: Quarterly Journal of Economics, "Public Versus Private Ownership of Firms: Evidence from Rural China." Volume 113, no. 3, Aug. 1998, 773-808.

No. 27: East-West Joint Ventures in a Transitional Economy: The Case of Slovakia

No. 26: Published in Economic Analysis "Behavior of a Slovenian Firm in Transition" Vol. 1, no. 1, 1998, 57-73.

No. 25: Cultural Encounters and Claims to Expertise in Postcommunist Capitalism

No. 24: ZVU a.s.: Investment Funds on the Board of Directors of an Engineering Giant

No. 23: The Role of Investment Funds in the Czech Republic (joint publication with Czech Management Center)

No. 22: Czech Investment Fund Industry: Development and Behaviour (joint publication with Czech Management Center)

No. 21: Restructuring of Czech Firms: An Example of Gama, a.s. (joint publication with Czech Management Center)

No. 20: YSE Funds: A Story of Czech Investment Funds (joint publication with Czech Management Center)

No. 19: První Investicni a.s., The First Investment Corporation (joint publication with Czech Management Center)

No. 18: PPF a.s., The First Private Investment Fund (joint publication with Czech Management Center)

No. 17 Published in: Post-Soviet Geography and Economics, "Russia's Managers in Transition: Pilferers or Paladins?" 37(7) (Sept. 1996), pp. 397-426.

\begin{tabular}{|c|c|}
\hline $\begin{array}{l}\text { Simon Commander, Andrei } \\
\text { Tolstopiatenko, and Ruslan } \\
\text { Yemtsov }\end{array}$ & May 1997 \\
\hline László Halpern and Gabor Korosi & May 1997 \\
\hline Michael Heller & Feb. 1997 \\
\hline $\begin{array}{l}\text { Olivier Debande and Guido } \\
\text { Friebel }\end{array}$ & May 1997 \\
\hline $\begin{array}{l}\text { Olivier Blanchard and Michael } \\
\text { Kremer }\end{array}$ & Jan. 1997 \\
\hline $\begin{array}{l}\text { Gérard Roland and Thierry } \\
\text { Verdier }\end{array}$ & Mar. 1997 \\
\hline Richard Ericson & Sept. 1996 \\
\hline $\begin{array}{l}\text { Sonia Ferencikova and Vern } \\
\text { Terpstra }\end{array}$ & Dec. 1998 \\
\hline $\begin{array}{l}\text { Daniel Berkowitz, David DeJong, } \\
\text { and Steven Husted }\end{array}$ & Dec. 1998 \\
\hline John McMillan & Sept. 1996 \\
\hline Yijiang Wang and Chun Chang & Mar. 1997 \\
\hline Saul Estrin and Giovanni Urga & Feb. 1997 \\
\hline Evzen Kocenda & Mar. 1997 \\
\hline Hehui Jin and Yingyi Qian & Jan. 1997 \\
\hline Sonia Ferencikova & Mar. 1997 \\
\hline Janez Prasnikar & Feb. 1997 \\
\hline Michael D. Kennedy & Feb. 1997 \\
\hline Tory Wolff & Aug. 1995 \\
\hline Dusan Triska & June 1996 \\
\hline Richard Podpiera & May 1996 \\
\hline Antonin Bulin & June 1996 \\
\hline Michal Otradovec & Nov. 1995 \\
\hline Jaroslav Jirasek & Aug. 1995 \\
\hline Michal Otradovec & Nov. 1995 \\
\hline Susan J. Linz and Gary Krueger & Nov. 1996 \\
\hline
\end{tabular}




\begin{tabular}{|c|c|c|c|}
\hline \multicolumn{2}{|c|}{$\begin{array}{l}\text { No. 16: Banks in Transition-Investment Opportunities in Central } \\
\text { Europe and Russia, Edited Transcript from } 31 \text { May } 1996 \text { Conference in } \\
\text { New York City }\end{array}$} & $\begin{array}{l}\text { With commentary and edited by } \\
\text { Anna Meyendorff }\end{array}$ & Jan. 19 \\
\hline \multicolumn{2}{|c|}{$\begin{array}{l}\text { No. 15: Marketing in Transitional Economies: Edited Transcript \& } \\
\text { Papers from } 1 \text { Apr. } 1996 \text { Conference in Ann Arbor, Michigan }\end{array}$} & $\begin{array}{l}\text { Compiled } \\
\text { Institute }\end{array}$ & Dec. 1996 \\
\hline \multicolumn{2}{|c|}{$\begin{array}{l}\text { No. 14: Pensions in the Former Soviet Bloc: Problems and Solutions. } \\
\text { Published by Council on Foreign Relations. "The Coming Global } \\
\text { Pension Crisis" New York, } 1997\end{array}$} & Jan Svejnar & Nov. 1996 \\
\hline \multicolumn{2}{|c|}{$\begin{array}{l}\text { No. 13: Enterprise Restructuring and Performance in the Transition. } \\
\text { Forthcoming in Financial Systems in Transition: The Design of } \\
\text { Financial Systems in Central Europe eds. Anna Meyendorff and Anjan } \\
\text { Thakor. }\end{array}$} & $\begin{array}{l}\text { Lubomir Lizal, Mirosla } \\
\text { and Jan Svejnar }\end{array}$ & Dec. 1996 \\
\hline \multicolumn{2}{|c|}{$\begin{array}{l}\text { No. } 12 \text { Published in: Journal of International Marketing, "Executive } \\
\text { Insights: Marketing Issues and Challenges in Transitional Economies." } \\
\text { Vol. 5, No. 4, 1997, pp. 95-114. Also published in: Marketing Issues in } \\
\text { Transitional Economies ed. Rajeev Batra. }\end{array}$} & Rajeev Batra & Apr. 1997 \\
\hline \multicolumn{2}{|c|}{$\begin{array}{l}\text { No. 11: Worker Trust and System Vulnerability in the Transition from } \\
\text { Socialism to Capitalism }\end{array}$} & Anc & Aug. 1996 \\
\hline \multicolumn{2}{|c|}{$\begin{array}{l}\text { No. } 10 \text { Published in: Comparative Economic Studies, "Russian Firms in } \\
\text { Transition: Champions, Challengers, and Chaff." Vol. 39, No.2, } \\
\text { Summer 1997, pp. 1-36. }\end{array}$} & . Lint & 1996 \\
\hline \multicolumn{2}{|l|}{$\begin{array}{l}\text { No. 9: Corporate Debt Crisis and Bankruptcy Law During the } \\
\text { Transition: The Case of China }\end{array}$} & David D. Li & Dec. 1995 \\
\hline \multicolumn{2}{|c|}{$\begin{array}{l}\text { No. } 8 \text { Published in: Journal of Comparative Economics, "A Theory of } \\
\text { Ambiguous Property Rights in Transition Economies: The Case of the } \\
\text { Chinese Non-State Sector." Vol. 23, No. 1, Aug. 1996, pp. 1-19. }\end{array}$} & $\mathrm{Da}$ & June 1996 \\
\hline \multicolumn{2}{|l|}{$\begin{array}{l}\text { No. 7: The Foreign Economic Contract Law of China: Cases and } \\
\text { Analysis }\end{array}$} & Do & June 1993 \\
\hline \multicolumn{2}{|c|}{$\begin{array}{l}\text { No. 3: Bank Privatization in Hungary and the Magyar Kulkereskedelmi } \\
\text { Bank Transaction }\end{array}$} & $\begin{array}{l}\text { Kormendi and Karen } \\
\text { tterly }\end{array}$ & May 1996 \\
\hline $\begin{array}{l}\text { Replacing No. 1: Journal of Comparative Economics } \\
\text { Symposium on "Bank Privatization in Central Europe and } \\
\text { Russia." Vol. 25, No. 1, Aug. } 1997 .\end{array}$ & \multicolumn{2}{|c|}{$\begin{array}{l}\text { Economies," Roger Kormendi and Edward } \\
\text { Snyder. }\end{array}$} & Aug. 1997 \\
\hline $\begin{array}{l}\text { Replacing No. 2: Journal of Comparative Economics } \\
\text { Symposium on "Bank Privatization in Central Europe and } \\
\text { Russia." Vol. 25, No. 1, Aug. } 1997 .\end{array}$ & \multicolumn{2}{|c|}{$\begin{array}{l}\text { "Transactional Structures of Bank } \\
\text { Privatizations in Central Europe and } \\
\text { Russia," Anna Meyendorff and Edward A. } \\
\text { Snyder. }\end{array}$} & Aug. 1997 \\
\hline $\begin{array}{l}\text { Replacing No. 4: Journal of Comparative Economics } \\
\text { Symposium on "Bank Privatization in Central Europe } \\
\text { Russia." Vol. 25, No. 1, Aug. } 1997 .\end{array}$ & \multicolumn{2}{|c|}{$\begin{array}{l}\text { "Bank Privatization in Poland: The Case of } \\
\text { Bank Slaski," Jeffery Abarbaness and John } \\
\text { Bonin. }\end{array}$} & Aug. 1997 \\
\hline $\begin{array}{l}\text { Replacing No. 5: Journal of Comparative Economics } \\
\text { Symposium on "Bank Privatization in Central Europe an } \\
\text { Russia." Vol. 25, No. 1, Aug. } 1997 .\end{array}$ & \multicolumn{2}{|c|}{$\begin{array}{l}\text { "Bank Privatization in Post-Communist } \\
\text { Russia: The Case of Zhilsotsbank," Jeffery } \\
\text { Abarbanell and Anna Meyendorff }\end{array}$} & Aug. 1997 \\
\hline $\begin{array}{l}\text { Replacing No. 6: Journal of Comparative Economics } \\
\text { Symposium on "Bank Privatization in Central Europe a } \\
\text { Russia." Vol. 25, No. 1, Aug. } 1997 .\end{array}$ & \multicolumn{2}{|c|}{$\begin{array}{l}\text { "The Czech Republic's Commercial Bank: } \\
\text { Komercni Banka," Edward A. Snyder and } \\
\text { Roger C. Kormendi. }\end{array}$} & Aug. 1997 \\
\hline
\end{tabular}

